\title{
Rhodium(III) and Iridium(III) Complexes of a NHC-Based Macrocycle: Persistent Weak Agostic Interactions and Reactions with Dihydrogen
}

\author{
Matthew R. Gyton, ${ }^{\circledR}$ Baptiste Leforestier, ${ }^{\circledR}$ and Adrian B. Chaplin*두 \\ Department of Chemistry, University of Warwick, Gibbet Hill Road, Coventry CV4 7AL, U.K.
}

Supporting Information

ABSTRACT: The synthesis and characterization of fivecoordinate rhodium(III) and iridium(III) 2,2'-biphenyl complexes $[\mathrm{M}(\mathrm{CNC}-12)(\mathrm{biph})]\left[\mathrm{BAr}^{\mathrm{F}}{ }_{4}\right](\mathrm{M}=\mathrm{Rh}(\mathbf{1 a}), \mathrm{Ir}$ (1b)), featuring the macrocyclic lutidine- and NHC-based pincer ligand CNC-12 are reported. In the solid state these complexes are notable for the adoption of weak $\varepsilon$-agostic interactions that are characterized by $M \cdots \mathrm{H}-\mathrm{C}$ contacts of ca. $3.0 \AA$ by X-ray crystallography and $\nu(\mathrm{CH})$ bands of reduced

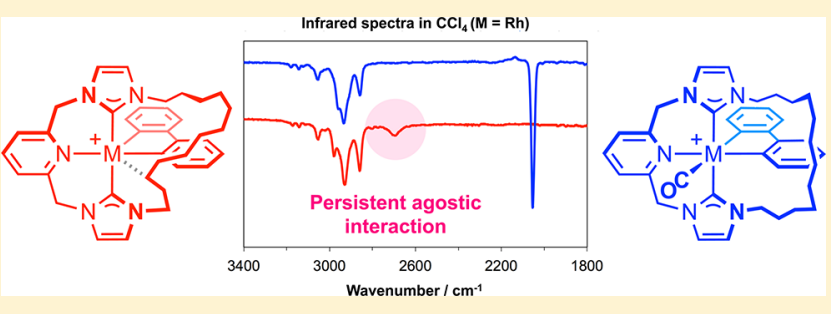
wavenumber by ATR IR spectroscopy. Remarkably, these interactions persist on dissolution and were observed at room temperature using NMR spectroscopy $\left(\mathrm{CD}_{2} \mathrm{Cl}_{2}\right)$ and solutionphase IR spectroscopy $\left(\mathrm{CCl}_{4}\right)$. The associated metrics point toward a stronger $\mathrm{M} \cdots \mathrm{H}-\mathrm{C}$ interaction in the iridium congener, and this conclusion is borne out on interrogation of $\mathbf{1}$ in silico using DFT-based NBO and QTAIM analyses. Reaction of $\mathbf{1}$ with dihydrogen resulted in hydrogenolysis of the biaryl and formation of fluxional hydride complexes, whose ground state formulations as $\left[\mathrm{Rh}(\mathrm{CNC}-12) \mathrm{H}_{2}\right]\left[\mathrm{BAr}_{4}^{\mathrm{F}}\right]\left(\mathbf{2} \mathbf{a}^{\prime \prime}\right)$ and $\left[\operatorname{Ir}(\mathrm{CNC}-12) \mathrm{H}_{2}\left(\mathrm{H}_{2}\right)\right]\left[\mathrm{BAr}^{\mathrm{F}}{ }_{4}\right]\left(\mathbf{2} \mathbf{b}^{\prime \prime \prime}\right)$ are proposed on the basis of inversion recovery and variable-temperature NMR experiments, alongside a computational analysis. Reactions of 1 and 2 with carbon monoxide help support their respective structural properties.

\section{INTRODUCTION}

Conferring high thermal stability and supporting a wide range of metal-based reactivity, mer-tridentate "pincer" ligands have become ubiquitous in contemporary organometallic chemistry and homogeneous catalysis. ${ }^{1}$ Examples featuring terminal phosphine donors are prototypical, but driven by favorable bonding and steric characteristics, N-heterocyclic carbene $(\mathrm{NHC})$ congeners are attracting growing interest. ${ }^{2}$ In addition to their successful use as ancillary ligands in a wide variety of transition-metal-catalyzed reactions, their coordination has also been shown to confer useful photophysical and electrochemical properties. ${ }^{2,3}$

Curiously and despite the enduring prominence of these metals in homogeneous catalysis, ${ }^{4}$ the organometallic chemistry of rhodium and iridium complexes of NHC-based pincer ligands is significantly underdeveloped. Indeed, current knowledge is largely confined to oxidative addition reactions of alkyl halides and other strong oxidants with CNC pincer complexes (Figure 1). ${ }^{5,6}$ Underlying this paucity, the potential of modern synthetic protocols for accessing NHC adducts of suitably reactive rhodium- and iridium-containing fragments is only now starting to be realized. For instance, building upon a comparative study of the efficacy of coinage metal transfer agents, ${ }^{7}$ we have recently reported the synthesis of labile rhodium(I) ethylene complexes $\mathbf{C}$ and $\mathbf{D}$ through transmetalation reactions of the respective copper(I) derivatives with $\left[\mathrm{Rh}\left(\mathrm{C}_{2} \mathrm{H}_{4}\right)_{2} \mathrm{Cl}\right]_{2} .{ }^{8}$ These complexes act as latent sources of reactive three-coordinate $\mathrm{Rh}(\mathrm{I})$ fragments and promote

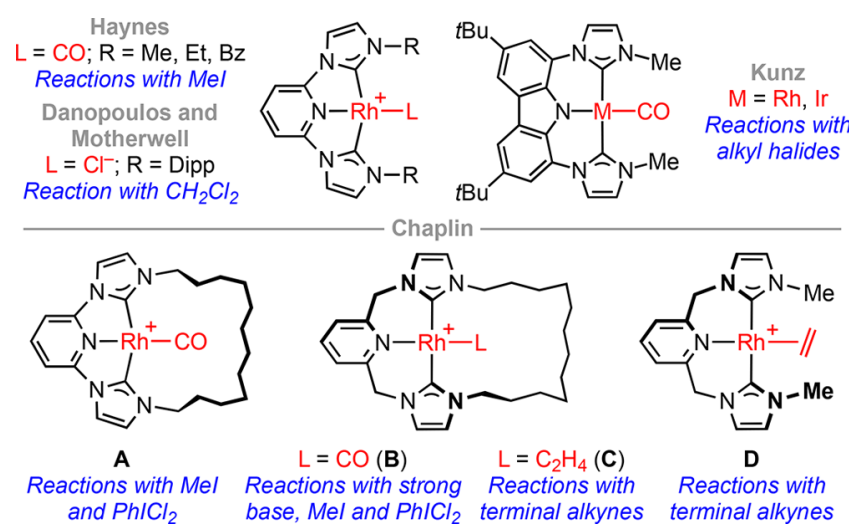

Figure 1. Organometallic chemistry of rhodium and iridium $\mathrm{CNC}$ complexes.

selective terminal alkyne coupling reactions, following initial and facile $\mathrm{C}(\mathrm{sp})-\mathrm{H}$ bond activation.

In the context of advancing the organometallic chemistry of group 9 NHC-based pincers, and informed by preceding work in our laboratories, ${ }^{6-11}$ in this report we describe the straightforward synthesis, isolation, and characterization of low-coordinate rhodium(III) and iridium(III) 2,2'-biphenyl complexes $[\mathrm{M}(\mathrm{CNC}-12)(\mathrm{biph})]\left[\mathrm{BAr}_{4}^{\mathrm{F}}\right](\mathrm{M}=\mathrm{Rh}(\mathbf{1 a}), \mathrm{Ir}$

Received: August 17, 2018

Published: October 9, 2018 
(1b); $\mathrm{Ar}^{\mathrm{F}}=3,5-\left(\mathrm{CF}_{3}\right)_{2} \mathrm{C}_{6} \mathrm{H}_{3} ;$ Scheme 1) featuring a macrocyclic lutidine-based pincer ancillary. These complexes are

Scheme 1. Synthesis of 1 by Transmetalation ${ }^{a}$<smiles></smiles>
[Rh(biph)(dtbpm)Cl], $\mathrm{Na}^{+}$
or $0.5\left[\mathrm{Ir}(\right.$ biph $)(\mathrm{COD}) \mathrm{Cl}_{2}$$\underset{\mathrm{CH}_{2} \mathrm{Cl}_{2}, \mathrm{RT}}{\longrightarrow}$

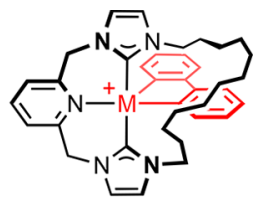
$M=\operatorname{Rh}(\mathbf{1}), \operatorname{Ir}(\mathbf{1 b})$

${ }^{a}\left[\mathrm{BAr}_{4}\right]^{-}$counteranions are omitted for clarity.

stabilized by adoption of agostic interactions ${ }^{12}$ and serve as precursors for catalytically relevant hydride derivatives 2 through hydrogenolysis of the biaryl. The structure and reactivity of these metal hydrides are contrasted with the aid of DFT calculations.

\section{RESULTS AND DISCUSSION}

Exploiting the aforementioned copper(I)-based transmetalation methodology, reactions between $[\mathrm{Rh}(\mathrm{biph})(\mathrm{dtbpm}) \mathrm{Cl}]^{13}$ $(\mathrm{dtbpm}=$ bis (di-tert-butylphosphino)methane $)$ or $[\operatorname{Ir}(\mathrm{biph})$ $(\mathrm{COD}) \mathrm{Cl}]_{2}(\mathrm{COD}=1,5 \text {-cyclooctadiene })^{14}$ and $[\mathrm{Cu}(\mathrm{CNC}$ 12) $]\left[\mathrm{BAr}_{4}^{\mathrm{F}}\right]^{7}$ were employed for the preparation of 1 (Scheme $1)$. These reactions resulted in quantitative transfer of the pincer to the platinum-group metal; however, in the case of the rhodium(III) derivative, formation of a copper(I) diphosphine byproduct necessitated addition of excess $\mathrm{Na}\left[\mathrm{BAr}_{4}^{\mathrm{F}}{ }_{4}\right.$ to ensure complete removal of the halogen ion. The formally fivecoordinate 16-VE $\mathrm{M}$ (III) products were readily isolated as crystalline materials in high yield (1a, 95\%; 1b, 77\%) and extensively characterized in solution and the solid state, including the use of single-crystal X-ray crystallography.

Single crystals of 1 were obtained by recrystallization from $\mathrm{CH}_{2} \mathrm{Cl}_{2}$ /hexane at room temperature, although with different morphologies (1a, $P \overline{1}$ with $Z^{\prime}=1 ; 1 \mathbf{b}, P 2_{1} / c$ with $Z^{\prime}=2$; Figure 2 and Table 1). Despite these lattice differences, both feature a common molecular structure for all the corresponding cations that is characterized by $C_{1}$ symmetry, a squarebased-pyramidal geometry about the metal, and a skewed dodecamethylene chain that is distorted in such a manner as to enable formation of an $\varepsilon$-agostic interaction $(M \cdots \mathrm{H}-C$ ca. 3.0
Table 1. Selected Bond Lengths (A) and Angles (deg)

\begin{tabular}{|c|c|c|c|}
\hline & 1a $(M=R h)$ & $\mathbf{1 b}(\mathrm{M}=\mathrm{Ir})$ & $\mathbf{1 b}(\mathrm{M}=\mathrm{Ir})^{a}$ \\
\hline $\mathrm{M} 1-\mathrm{C} 2$ & $1.992(3)$ & $2.018(4)$ & $2.010(4)$ \\
\hline $\mathrm{M} 1-\mathrm{C} 13$ & $2.021(2)$ & $2.026(4)$ & $2.032(4)$ \\
\hline $\mathrm{M} 1-\mathrm{C} 28$ & $2.054(2)$ & $2.052(4)$ & $2.056(4)$ \\
\hline $\mathrm{M} 1-\mathrm{C} 34$ & $2.060(2)$ & $2.056(4)$ & $2.066(4)$ \\
\hline$\angle \mathrm{C} 28-\mathrm{M} 1-\mathrm{C} 34$ & $171.33(9)$ & $170.8(2)$ & $171.8(2)$ \\
\hline $\mathrm{M} 1-\mathrm{N} 20$ & $2.235(2)$ & $2.215(3)$ & $2.228(3)$ \\
\hline$M 1 \cdots H-C 40$ & 2.24 & 2.22 & 2.19 \\
\hline$M 1 \cdots \mathrm{H}-C 40$ & $3.000(3)$ & $2.999(4)$ & $2.978(5)$ \\
\hline$\angle \mathrm{M} 1 \cdots \mathrm{H}-\mathrm{C} 40$ & 133.1 & 134.5 & 135.1 \\
\hline
\end{tabular}

${ }^{a}$ Atom names in this independent cation differ by 10 (Ir) or 100 (C, $\mathrm{N})$.

$\AA$ ). Coordination of $2,2^{\prime}$-biphenyl is associated with a considerable disparity between the trans $\mathrm{C}-\mathrm{H} \cdots M-C($ biph) and $\mathrm{N}-\mathrm{M}-\mathrm{C}$ (biph) bond lengths (ca. $2 \mathrm{pm}$ ). Combined, these metrics point to weak $\mathrm{M} \cdots \mathrm{H}-\mathrm{C}$ interactions, ${ }^{9,12}$ however, the contorted nature of the macrocycle suggests that they nevertheless play an important stabilizing role. Comparison between the structurally related rhodium and iridium cations indicates there is a trend toward shorter $M \cdots$ $\mathrm{H}-\mathrm{C}$ contacts in the heavier congeners, but the difference is not statistically significant within the data set collected.

The adoption of meaningful agostic interactions in the solidstate is supported by ATR IR spectroscopy (Figures S7 and $\mathrm{S} 20){ }^{15}$ with broad $\nu(\mathrm{CH})$ bands of reduced wavenumber observed for 1a $\left(2682 \mathrm{~cm}^{-1}\right)$ and, supporting the trend for stronger agostic interactions in the third-row congener noted by X-ray crystallography, to a greater extent $1 \mathbf{b}\left(2571 \mathrm{~cm}^{-1}\right)$. These bands are not observed in the corresponding carbonyl derivatives (3; vide infra).

In order to further interrogate the nature of the $\mathrm{M} \cdots \mathrm{H}-\mathrm{C}$ interactions observed in the solid state for 1 , we turned to DFT-based computational methods. Cations of 1 were optimized at the $\omega$ B97X-D3 level of theory and analyzed using the natural bond orbital (NBO) and quantum theory of atoms in molecules (QTAIM) approaches (Table 2). ${ }^{16-18}$ In both cases, the presence of stabilizing agostic interactions in $\mathbf{1}$ is corroborated through identification of significant NBO perturbation energies associated with $\sigma_{\mathrm{CH}} \rightarrow \mathrm{ML}^{*}$ and $\mathrm{ML} \rightarrow$ $\sigma^{*}{ }_{\mathrm{CH}}$ bonding, with the former contributions particularly pronounced in comparison to the latter, and associated
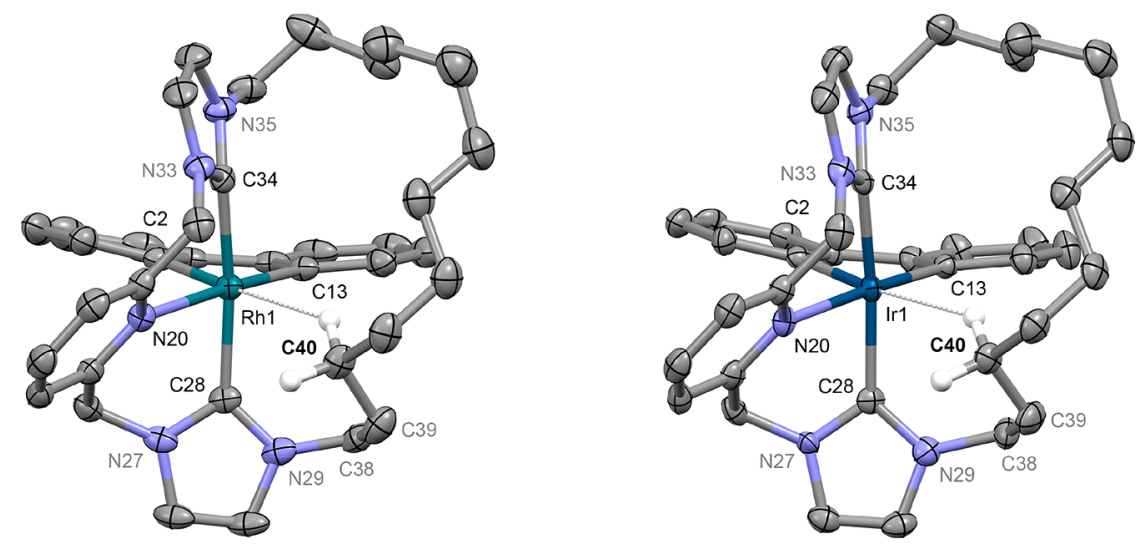

Figure 2. Solid-state structures of $\mathbf{1 a}$ (left) and $\mathbf{1 b}$ (right, only one unique cation shown). Thermal ellipsoids are drawn at $50 \%$ probability; solvent molecules, anions, minor disordered components, and most hydrogen atoms are omitted for clarity. Key metrics for all crystallographically independent cations are provided in Table 1 . 
Table 2. Calculated Geometric, NBO, and QTAIM Properties of 1

\begin{tabular}{lcc} 
& $\mathbf{1 a}(\mathrm{M}=\mathrm{Rh})$ & $\mathbf{1 b}(\mathrm{M}=\mathrm{Ir})$ \\
$M \cdots H-\mathrm{C} / \AA$ & 2.22 & 2.17 \\
$M \cdots \mathrm{H}-\mathrm{C} / \AA$ & 3.10 & 3.04 \\
$\angle \mathrm{M} \cdots \mathrm{H}-\mathrm{C} / \mathrm{deg}$ & 133.7 & 132.1 \\
$\Delta E^{2}\left(\sigma_{\mathrm{CH}} \rightarrow \mathrm{ML}^{*}\right) / \mathrm{kcal} \mathrm{mol}^{-1}$ & 11.83 & 18.68 \\
$\Delta E^{2}\left(\mathrm{ML} \rightarrow \sigma^{*}{ }_{\mathrm{CH}}\right) / \mathrm{kcal} \mathrm{mol}^{-1}$ & 7.15 & 7.13 \\
occ $\sigma_{\mathrm{CH}} \mathrm{NBO}$ & 1.953 & 1.936 \\
occ $\sigma_{\mathrm{CH}}^{*} \mathrm{NBO}$ & 0.023 & 0.027 \\
$\rho(M \cdots H-\mathrm{C})$ & 0.024 & 0.034 \\
$\nabla^{2} \rho(M \cdots H-\mathrm{C})$ & +0.083 & +0.114 \\
$K(M \cdots H-\mathrm{C})$ & +0.002 & +0.001 \\
$\mathrm{DI}(M \cdots H-\mathrm{C})$ & 0.114 & 0.130 \\
\hline
\end{tabular}

changes in the population of the $\sigma_{\mathrm{CH}}(1.953 / 1.936 \mathrm{cf} .1 .982 /$ 1.982 for the distal germinal $\mathrm{CH}$ bond) and $\sigma^{*}{ }_{\mathrm{CH}}(0.023 /$ 0.027 cf. $0.012 / 0.012$ for the distal germinal $\mathrm{CH}$ bond) NBO., ${ }^{9,19}$ Likewise, examination of the electron density topology reveals curved bond paths between the metal centers and the proximal hydrogen atoms and associated critical point properties $\left(\rho_{\mathrm{MH}}=0.024 / 0.034 ; \nabla^{2} \rho_{\mathrm{MH}}=+0.083 /+0.114\right.$; DI $=$ $0.114 / 0.130)$ symptomatic of agostic interactions. ${ }^{9,19}$ Overall, the calculated properties confirm the formation of stronger $\mathrm{M} \cdots \mathrm{H}-\mathrm{C}$ interactions in $\mathbf{1 b}$ in comparison to $\mathbf{1 a}$ inferred from experiment.

In $\mathrm{CD}_{2} \mathrm{Cl}_{2}$ solution 1 demonstrate overall $C_{1}$ symmetry on the NMR time scale across a wide temperature range (185$298 \mathrm{~K}, 500 \mathrm{MHz}$ ), with notable spectroscopic features including pairs of carbenic $\left(\delta 176.0\left({ }^{1} J_{\mathrm{RhC}}=44 \mathrm{~Hz}\right) / 174.5\right.$ $\left({ }^{1} J_{\mathrm{RhC}}=42 \mathrm{~Hz}\right)$ and $\left.165.9 / 163.3\right)$ and aryl $\left(\delta 163.8\left({ }^{1} J_{\mathrm{RhC}}=\right.\right.$ $38 \mathrm{~Hz}) / 155.7\left({ }^{1} J_{\mathrm{RhC}}=45 \mathrm{~Hz}\right)$ and $\left.142.9 / 125.5\right){ }^{13} \mathrm{C}$ resonances at $298 \mathrm{~K}$. Curiously, magnetization transfer between different pairs of diastereotopic $\mathrm{pyCH}_{2}$ and $\mathrm{NCH}_{2}$ resonances was detected from the ${ }^{1} \mathrm{H}-{ }^{1} \mathrm{H}$ NOESY spectra of 1 $(298 \mathrm{~K}, 600 \mathrm{MHz}){ }^{20}$ indicating that slow atropisomerism of the pincer ligand occurs in solution (Figures S6 and S19). ${ }^{10}$ Similarly the $\Delta \delta$ value for one of the two diastereotopic $\mathrm{pyCH}_{2}$ pairs is appreciably temperature dependent for both complexes (Figures S4 and S17). No magnetization transfer was, however, observed for the biphenyl ${ }^{1} \mathrm{H}$ resonances, suggesting that fluxionality of $\mathbf{1}$ does not involve movement of this ligand through the cavity of the macrocycle.

In the context of the adoption of agostic interactions in solution, 1 displays notably low frequency ${ }^{1} \mathrm{H}$ (integral $1 \mathrm{H}$ multiplets centered at $\delta 0.40$ and 0.29 for $1 \mathrm{a}$ and $\delta 0.46$ and -0.66 for $1 \mathbf{b}$ ) and ${ }^{13} \mathrm{C}$ resonances for both $\mathrm{NCH}_{2} \mathrm{CH}_{2} \mathrm{CH}_{2}$ groups (as established from HMBC experiments) at $298 \mathrm{~K}$ $(500 \mathrm{MHz})$. Such characteristics are consistent with adoption of an $\varepsilon$-agostic interaction; however, the twisted $C_{2}$ geometry of the pincer scaffold reasonably permits only one of these methylene groups to be engaged with the metal in this way. Inspection of the solid-state structures suggests a proton of the other could be projected inside the ring current of the biphenyl ancillary, reconciling a low chemical shift. On the basis of the degree of shielding, greater chemical shift temperature dependence (298-185 K; shifting to lower frequency on cooling), lower ${ }^{1} J_{\mathrm{CH}}$ coupling constants (averaged over the diastereotopic protons: $121 / 120 \mathrm{vs} 126 \mathrm{~Hz}$ ), and comparison between the data of the two congeners, we assign the lowest frequency signals to the $\varepsilon$-agostic interaction $\left(\delta^{1} \mathrm{H} 0.29, \delta^{13} \mathrm{C}\right.$ 22.2 for $1 \mathrm{a} ; \delta_{\mathrm{H}}-0.66, \delta^{13} \mathrm{C} 21.7$ for $1 \mathrm{~b}$ ).
Further evidence for the persistence of agostic interactions in solution was gathered using solution-phase IR spectroscopy: spectra of 1 recorded at room temperature in $\mathrm{CCl}_{4}$ show broad, reduced frequency $\nu(\mathrm{CH})$ stretching bands (1a, 2694 $\mathrm{cm}^{-1}$, Figure 3; 1b, $2577 \mathrm{~cm}^{-1}$, Figure S21) that are not

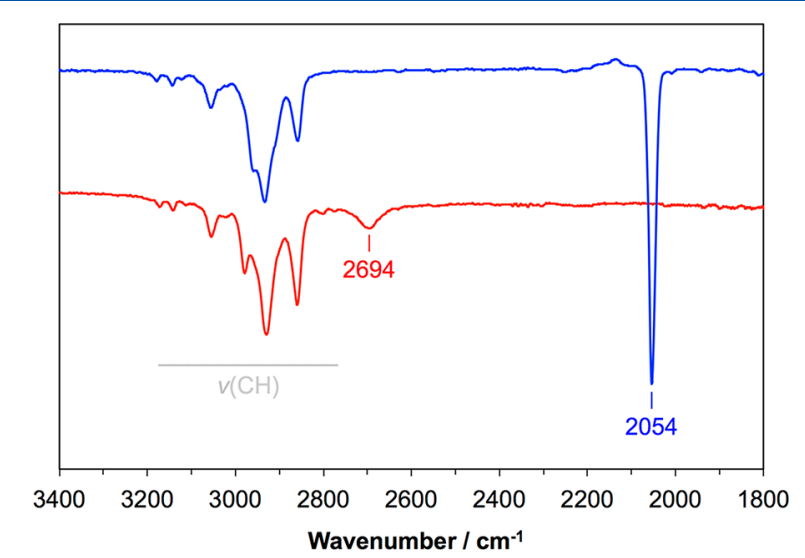

Figure 3. IR spectra of 1a (red) and 3a (blue) recorded in $\mathrm{CCl}_{4}$.

present in spectra of the respective carbonyl derivatives 3 (vide infra). Gratifyingly, these data are in good agreement with those collected in the solid state using ATR IR spectroscopy and strengthen the previous assertion regarding the relative strengths of the Ir $\cdots \mathrm{H}-\mathrm{C}$ and $\mathrm{Rh} \cdots \mathrm{H}-\mathrm{C}$ interactions.

Supplementing the experimental and computational structural analyses, the electronic properties of 1 were probed by formation of the corresponding carbonyl adducts $\mathbf{3}$ (Scheme 2 ). These coordinately saturated derivatives were straightfor-

\section{Scheme 2. Carbonyl Adducts of $\mathbf{1}^{a}$}

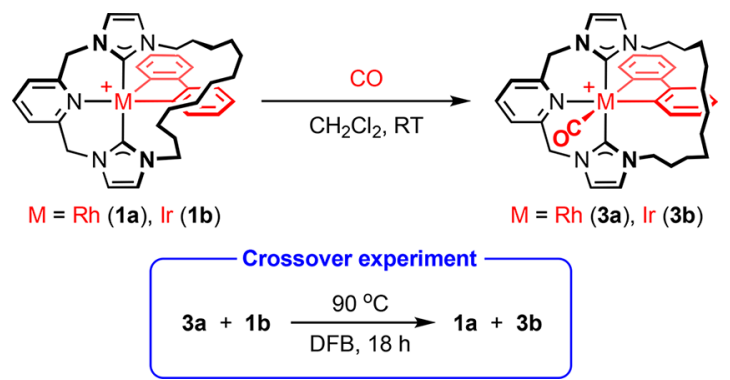

${ }^{a}\left[\mathrm{BAr}_{4}^{\mathrm{F}}\right]^{-}$counteranions are omitted for clarity.

wardly prepared by reaction of 1 with carbon monoxide (1 atm), isolated in good yield, and fully characterized, including in the solid state using X-ray crystallography $\left(3 \mathbf{b}\left(Z^{\prime}=1\right)\right.$ shown in Figure 4; 3a $\left(Z^{\prime}=2\right)$, CCDC 1862298). As a consequence of $\mathrm{CO}$ coordination, the solid-state structures of 3 show the expected displacement of the dodecamethylene chain away from the metal center and a significant increase in the opposing $\mathrm{M}-\mathrm{C}(\mathrm{biph})$ bond lengths in comparison to $\mathbf{1}$ (3a, 2.068(3)/2.073(3) vs $1.992(3) \AA ; 3 b, 2.106(2)$ vs $2.010(4) / 2.018(4) \AA$ ) , in line with trans-influence arguments. Stronger CO binding to iridium, in comparison to rhodium, is evident from the carbonyl stretching bands of 3 measured in $\mathrm{CH}_{2} \mathrm{Cl}_{2} / \mathrm{CCl}_{4}$ solution, viz. 2050/2054 (3a) and 2018/2022 (3b) $\mathrm{cm}^{-1}$, and from a crossover experiment between $3 a$ and $\mathbf{1 b}$, where quantitative $\mathrm{CO}$ transfer from rhodium to iridium was observed by ${ }^{1} \mathrm{H}$ NMR spectroscopy after heating in 1,2- 


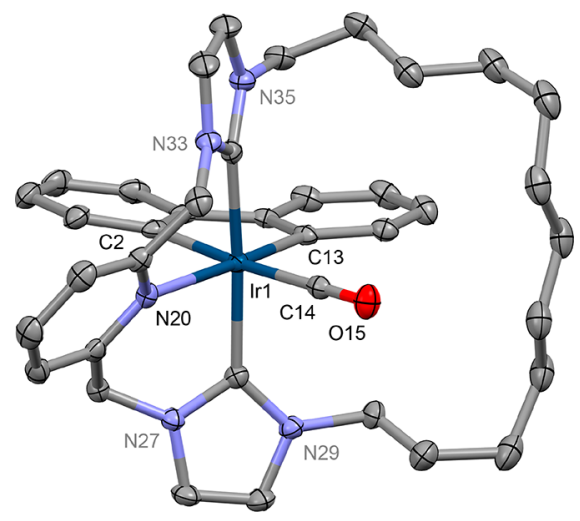

Figure 4. Solid-state structure of $\mathbf{3 b}$. Thermal ellipsoids are drawn at $50 \%$ probability; the anion and hydrogen atoms are omitted for clarity. Selected bond lengths (Å) and angles (deg): $\operatorname{Ir} 1-\mathrm{C} 2$, $2.106(2) ; \operatorname{Ir} 1-\mathrm{C} 13,2.057(2) ; \operatorname{Ir} 1-\mathrm{C} 14,1.916(2) ; \operatorname{Ir} 1-\mathrm{C} 28$, 2.090(2); Ir1-C34, 2.097(2); C28-Ir1-C34, 174.25(8); Ir1-N20, 2.228(2). Equivalent metrics for 3a $\left(Z^{\prime}=2\right)$ : Rh1-C2, 2.068(3); Rh1-C13, 2.054(3); Rh1-C14, 1.947(3); Rh1-C28, 2.100(3); Rh1-C34, 2.076(2); C28-Rh1-C34, 174.78(10); Rh1-N20, 2.230(2); Rh11-C102, 2.073(3); Rh11-C113, 2.041(3); Rh11C114, 1.949(3); Rh11-C128, 2.099(3); Rh11-C134, 2.076(3); C128-Rh11-C134, 175.43(11); Rh11-N120, 2.245(2).

difluorobenzene (DFB, Scheme 2). ${ }^{21,22}$ These data support the conclusion that stronger agostic interactions are formed in $\mathbf{1 b}$ in comparison to 1a. Moreover, complexes $\mathbf{3}$ also serve as useful references, helping confirm the spectroscopic features arising from the formation of agostic interactions, as noted above.

Hydrogenolysis of 2,2'-biphenyl proceeded quantitatively on reaction of 1 with dihydrogen (1 atm) at room temprature in $\mathrm{CD}_{2} \mathrm{Cl}_{2}$ (1a, $6 \mathrm{~h} ; \mathbf{1 b}, 24 \mathrm{~h}$; Scheme 3). The structures and

Scheme 3. Synthesis and Reactivity of Hydride Complexes 2

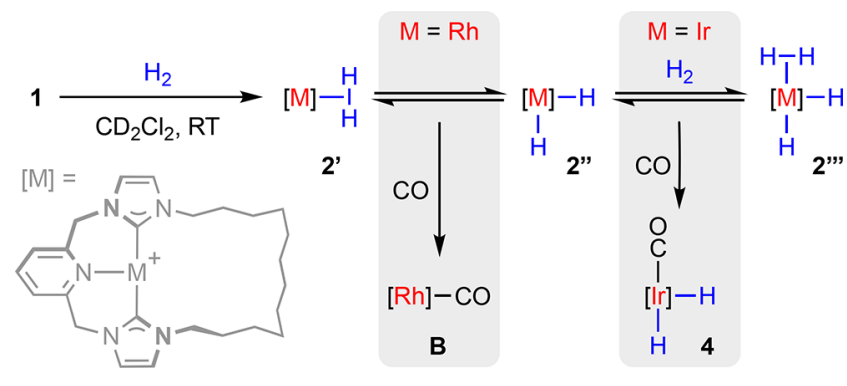

reactions of the resulting hydride complexes 2 a (>99\% yield) and $\mathbf{2 b}$ (ca. $95 \%$ yield) with carbon monoxide were studied in situ using NMR spectroscopy $(500 \mathrm{MHz})$, and these results are discussed below in turn. Attempts to isolate $\mathbf{2}$ from solution invariably lead to partial decomposition (Figures S34 and S42).

Rhodium hydride $\mathbf{2} \mathbf{a}$ is characterized by time-averaged $C_{2 v}$ symmetry and a broad $2 \mathrm{H}$ hydride signal at $\delta-18.87\left(T_{1}=\right.$ $643 \pm 19 \mathrm{~ms}$ ) under an atmosphere of dihydrogen. This high symmetry is principally attributed to fast atropisomerism of the pincer ligand on the NMR time scale and the associated set of ${ }^{1} \mathrm{H}$ resonances correspondingly became $C_{2}$ symmetric on cooling to $200 \mathrm{~K}$, while the hydride signal persisted at $\delta$ $-18.66\left(T_{1}=494 \pm 32 \mathrm{~ms}\right)$. Overall these data, and notably the measured $T_{1}$ relaxation values, ${ }^{23}$ are consistent with assignment of $\mathbf{2 a}$ as classical $\mathrm{Rh}$ (III) dihydride $\mathbf{2 a}$ " (Scheme $3)$. Indeed, a structure of this formulation, stabilized by an $\varepsilon$ agostic interaction $\left(\boldsymbol{\varepsilon}-\mathbf{2} \mathbf{a}^{\prime \prime}\right)$, is calculated to be the most thermodynamically preferred hydride derivative of 1 a $(\omega \mathrm{B} 97 \mathrm{X}-$ D3 level of theory, Figure 5). ${ }^{24}$ The optimized structures of

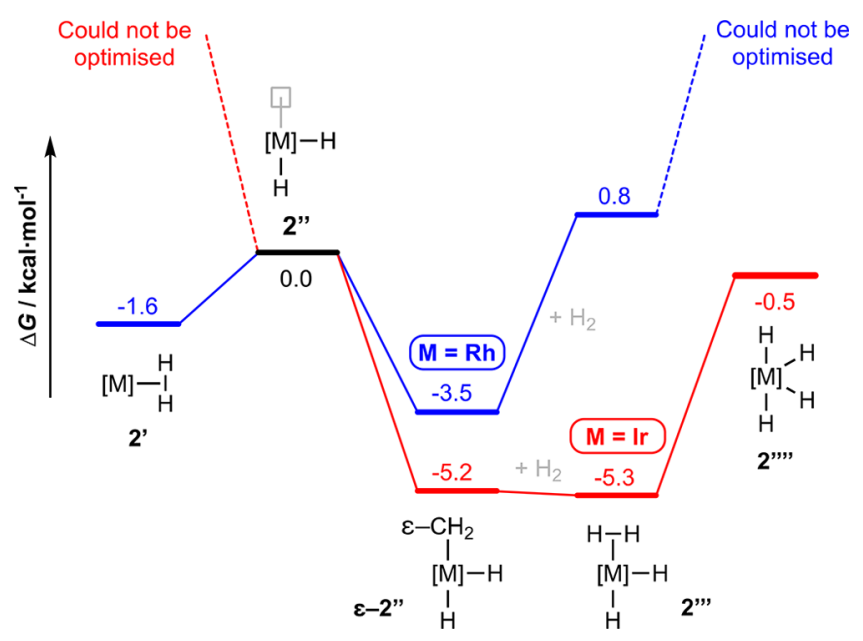

Figure 5. Calculated thermodynamics for rhodium (blue) and iridium (red) hydride complexes (relative to $\mathbf{2}^{\prime \prime}$ ).

$\mathbf{2 a}$ " and $\boldsymbol{\varepsilon}$-2a" exhibit square-based-pyramidal metal geometries, requiring the hydride ligands to be highly fluxional on the NMR time scale to reconcile the experimental findings. ${ }^{25,26}$ A plausible mechanism for such dynamics involves intermediate formation of $C_{2}$-symmetric $\mathrm{Rh}(\mathrm{I})$ dihydrogen complex $\mathbf{2} \mathbf{a}^{\prime}$, and the calculated barrier with respect to $\boldsymbol{\varepsilon}-\mathbf{2} \mathbf{a}^{\prime \prime}$ is estimated to be only $\Delta G^{\ddagger}=3.8 \mathrm{kcal} \mathrm{mol}^{-1}$. Similar spectroscopic features were observed upon removal of hydrogen and placement under an atmosphere of argon, although the hydride resonance at $\delta-18.89\left(T_{1}=754 \pm 23\right.$ $\mathrm{ms})$ is notable for the exhibition of ${ }^{103} \mathrm{Rh}$ coupling $\left({ }^{1} J_{\mathrm{RhH}}=\right.$ $40.6 \mathrm{~Hz}$ ) at $298 \mathrm{~K} .{ }^{13} \mathrm{C}$ NMR data for $2 \mathrm{a}$ were collected under argon, with the characteristics of the carbenic resonance at $\delta$ $182.8\left({ }^{1} J_{\mathrm{RhC}}=40 \mathrm{~Hz}\right)$ notable for their similarity to those of five-coordinate $\mathrm{Rh}(\mathrm{III}) \mathbf{1 a}\left(\mathrm{ca} . \delta 175\left({ }^{1} J_{\mathrm{RhC}}=44 \mathrm{~Hz}\right)\right)$, lending support to the assignment as $\mathbf{2 a "}$.

As for the lighter congener, iridium hydride $\mathbf{2 b}$ is characterized by time-averaged $C_{2 v}$ symmetry under hydrogen at $298 \mathrm{~K}$, with decoalescence of the $\mathrm{CNC}-12{ }^{1} \mathrm{H}$ resonances on cooling to $200 \mathrm{~K}$, indicative of fast atropisomerism of the pincer ligand. Differences, however, emerge on inspection of the hydride region of the ${ }^{1} \mathrm{H}$ NMR spectra, where a significantly more downfield $4 \mathrm{H}$ signal with considerably faster longitudinal relaxation is located at $\delta-9.46\left(T_{1}=94 \pm 5 \mathrm{~ms}\right.$, fwhm $=230 \mathrm{~Hz})$ at $298 \mathrm{~K}$ and $\delta-9.56\left(T_{1}=29 \pm 3 \mathrm{~ms}\right.$, fwhm $=80 \mathrm{~Hz}$ ) at $200 \mathrm{~K}$. We correspondingly account for this behavior by assignment of $\mathbf{2 b}$ as the fluxional Ir(III) dihydride dihydrogen complex $\mathbf{2} \mathbf{b}^{\prime \prime \prime}$. ${ }^{26,27}$ This assignment is also borne out in silico, with a 2 step pathway via $C_{2}$-symmetric $\mathbf{2} \mathbf{b}^{\prime \prime \prime \prime}$ providing an upper bound for the associated barrier of fluxional

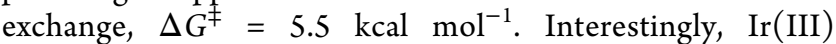
dihydride $\boldsymbol{\varepsilon}-\mathbf{2} \mathbf{b}^{\prime \prime}\left(+\mathrm{H}_{2}\right)$ is predicted to be essentially isoenergetic with $\mathbf{2 b}^{\prime \prime \prime}$ (Figure 5), ${ }^{24}$ although the latter is presumably favored in the presence of excess dihydrogen. Indeed, consistent with the computed thermodynamics, removal of volatiles and redissolution under argon results in the emergence of a new $C_{2 v}$-symmetric hydride complex at 298 
$\mathrm{K}$ that exhibits a $2 \mathrm{H}$ resonance at $\delta-24.53$ with considerably slower longitudinal relaxation $\left(T_{1}=727 \pm 16 \mathrm{~ms}\right)$, which we correspondingly assign to $\mathbf{2 b}^{\prime \prime}$. This is the major species observed on attempted isolation of $\mathbf{2} \mathbf{b}$ from solution.

Reactions with carbon monoxide provided further insights into the structure and dynamics of $\mathbf{2}$, with $\mathbf{2 a}$ affording the known $\mathrm{Rh}(\mathrm{I})$ carbonyl complex $\mathbf{B}^{6}$ and $\mathbf{2} \mathbf{b}$ the novel $\mathrm{Ir}(\mathrm{III})$ dihydride carbonyl 4 . The former reaction, trapping rhodium in the +1 oxidation state, provides a case for alternative ground-state assignment of $\mathbf{2 a}$ as $\mathrm{Rh}(\mathrm{I})$ dihydrogen complex $\mathbf{2} \mathbf{a}^{\prime}$ as opposed to $\mathrm{Rh}(\mathrm{III})$ dihydride $\mathbf{2} \mathbf{a}^{\prime \prime}$. In the context of the preceding discussion, we reconcile this observation by dynamic equilibration between $\mathbf{2} \mathbf{a}^{\prime \prime}$ and $\mathbf{2} \mathbf{a}^{\prime}$ in solution and faster/ irreversible reaction of $\mathrm{CO}$ with the latter. The formation of 4 , with diagnostic dihydride signals at $\delta-7.33\left({ }^{2} J_{\mathrm{HH}}=2.9 \mathrm{~Hz}, T_{1}\right.$ $=1120 \pm 18 \mathrm{~ms})$ and $-17.69\left({ }^{2} J_{\mathrm{HH}}=2.9 \mathrm{~Hz}, T_{1}=950 \pm 9\right.$ ms) and a carbonyl stretching band at $2062 \mathrm{~cm}^{-1}$, is more straightforwardly accounted for by direct reaction with $\mathbf{2} \mathbf{b}^{\prime \prime}$ or substitution of $\mathbf{2} \mathbf{b}^{\prime \prime \prime}$, with both of these presumably in rapid dynamic equilibrium.

\section{CONCLUSIONS}

Showcasing the effectiveness of copper-based transmetalation protocols, the straightforward preparation of five-coordinate formally $16 \mathrm{VE}$ rhodium(III) and iridium(III) complexes of a macrocyclic CNC pincer ligand have been described, [M$(\mathrm{CNC}-12)(\mathrm{biph})]\left[\mathrm{BAr}_{4}^{\mathrm{F}}\right](\mathrm{M}=\mathrm{Rh}(\mathbf{1 a}), \operatorname{Ir}(\mathbf{1 b}))$. These lowcoordinate complexes are stabilized by adoption of $\varepsilon$-agostic interactions, involving coordination of the flexible dodecamethylene chain of the macrocyclic ancillary, both in the solid state and, remarkably, in solution at room temperature. The adoption of these weak and typically transient $\mathrm{M} \cdots \mathrm{H}-\mathrm{C}$ interactions was directly evidenced using X-ray crystallography, ATR and solution-phase IR spectroscopy, and NMR spectroscopy and through comparison to coordinatively saturated derivatives $[\mathrm{M}(\mathrm{CNC}-12)(\mathrm{biph})(\mathrm{CO})]\left[\mathrm{BAr}^{\mathrm{F}}{ }_{4}\right](\mathrm{M}=\mathrm{Rh}(\mathbf{3 a})$, Ir $(3 \mathbf{b})$ ) formed on reaction with carbon monoxide. The associated metrics and spectroscopic features of 1 point toward a stronger $\mathrm{M} \cdots \mathrm{H}-\mathrm{C}$ interaction in the iridium congener, and this conclusion is borne out on interrogation in silico using DFT-based NBO and QTAIM analyses.

As a potentially generalizable and convenient method for generation of reactive group 9 complexes of NHC-based pincer ligands, reaction of $\mathbf{1}$ with dihydrogen resulted in hydrogenolysis of the biaryl species and formation of fluxional hydride complexes, whose ground state formulation as $\left[\mathrm{Rh}(\mathrm{CNC}-12) \mathrm{H}_{2}\right]\left[\mathrm{BAr}_{4}^{\mathrm{F}}\right]\left(\mathbf{2} \mathbf{a}^{\prime \prime}\right)$ and $\left[\mathrm{Ir}(\mathrm{CNC}-12) \mathrm{H}_{2}\left(\mathrm{H}_{2}\right)\right]$ $\left[\mathrm{BAr}_{4}^{\mathrm{F}}\right]\left(\mathbf{2} \mathbf{b}^{\prime \prime \prime}\right)$ is proposed on the basis of inversion recovery and variable-temperature NMR experiments, a DFT-based computational analysis, and reactions with carbon monoxide, forming $[\mathrm{Rh}(\mathrm{CNC}-12)(\mathrm{CO})]\left[\mathrm{BAr}^{\mathrm{F}}{ }_{4}\right]$ (B) and $[\mathrm{Ir}(\mathrm{CNC}-$ 12) $\left.\mathrm{H}_{2}(\mathrm{CO})\right]\left[\mathrm{BAr}_{4}^{\mathrm{F}}\right]$ (4), respectively.

\section{EXPERIMENTAL SECTION}

General Methods. All manipulations were performed under an atmosphere of argon using Schlenk and glovebox techniques unless otherwise stated. Glassware was oven-dried at $150{ }^{\circ} \mathrm{C}$ overnight and flame-dried under vacuum prior to use. Molecular sieves were activated by heating at $300{ }^{\circ} \mathrm{C}$ in vacuo overnight. 1,2Difluorobenzene was predried over $\mathrm{Al}_{2} \mathrm{O}_{3}$, distilled from calcium hydride, and dried twice over $3 \AA$ molecular sieves. ${ }^{22} \mathrm{CD}_{2} \mathrm{Cl}_{2}$ was freeze-pump-thaw degassed and dried over $3 \AA$ molecular sieves. Other anhydrous solvents were purchased from Acros Organics or
Sigma-Aldrich, freeze-pump-thaw degassed, and stored over $3 \AA$ molecular sieves. $\mathrm{Na}\left[\mathrm{BAr}_{4}^{\mathrm{F}}\right],{ }^{28}[\mathrm{Rh}(\mathrm{biph}) \mathrm{Cl}(\mathrm{dtbpm})],{ }^{13}[\mathrm{Ir}(\mathrm{biph}) \mathrm{Cl}-$ $(\mathrm{COD})]_{2},{ }^{14}$ and $[\mathrm{Cu}(\mathrm{CNC}-12)]\left[\mathrm{BAr}_{4}\right]^{7}$ were synthesized according to published procedures. All other reagents are commercial products and were used as received. NMR spectra were recorded on Bruker spectrometers under argon at $298 \mathrm{~K}$ unless otherwise stated. Chemical shifts are quoted in ppm and coupling constants in Hz. NMR spectra in 1,2-difluorobenzene were recorded using an internal capillary of $\mathrm{C}_{6} \mathrm{D}_{6} \cdot{ }^{22}$ ESI-MS were recorded on Bruker Maxis Plus (HR) or Agilent 6130B single Quad (LR) instruments. Infrared spectra were recorded on a PerkinElmer Spectrum 100 using either a $\mathrm{KBr}$ transmission cell in $\mathrm{CH}_{2} \mathrm{Cl}_{2}$ or $\mathrm{CCl}_{4}$ or an ATR module fitted with a diamond/ZnSe crystal. Microanalyses were performed at the London Metropolitan University by Stephen Boyer.

[Rh(CNC-12)(biph)][BArF $\left.{ }_{4}\right]$ (1a). A suspension of [Rh(biph)Cl(dtbpm)] (17.8 mg, $30.3 \mu \mathrm{mol}), \mathrm{Na}\left[\mathrm{BAr}_{4}^{\mathrm{F}}\right](31.9 \mathrm{mg}, 36.0 \mu \mathrm{mol})$, and $[\mathrm{Cu}(\mathrm{CNC}-12)]\left[\mathrm{BAr}_{4}^{\mathrm{F}}\right](40.3 \mathrm{mg}, 30.2 \mu \mathrm{mol})$ in $\mathrm{CH}_{2} \mathrm{Cl}_{2}$ (ca. 1 $\mathrm{mL}$ ) was stirred at ambient temperature for $2 \mathrm{~h}$, filtered and the precipitate washed with $\mathrm{CH}_{2} \mathrm{Cl}_{2}($ ca. $3 \times 0.5 \mathrm{~mL})$. Volatiles were removed in vacuo, and the product extracted into $\mathrm{Et}_{2} \mathrm{O}(\mathrm{ca} .3 \times 1$ $\mathrm{mL}$ ). (The ether-insoluble material appears to be a $\mathrm{Cu}(\mathrm{I})$ complex of dtbpm. ${ }^{31} \mathrm{P}\left\{{ }^{1} \mathrm{H}\right\}$ NMR (162 MHz, $\left.\mathrm{CD}_{2} \mathrm{Cl}_{2}\right): \delta 55.2(\mathrm{~s})$.) The filtrate and washings were layered with hexane (ca. $20 \mathrm{~mL}$ ) and stored at ambient temperature to afford the product as yellow blocks, which were isolated through decantation of the supernatant and dried in vacuo. Yield: $44.0 \mathrm{mg}$ (95\%). Single crystals suitable for X-ray diffraction were obtained by slow diffusion of hexane into a solution in $\mathrm{CH}_{2} \mathrm{Cl}_{2}$ at ambient temperature.

${ }^{1} \mathrm{H}$ NMR $\left(500 \mathrm{MHz}, \mathrm{CD}_{2} \mathrm{Cl}_{2}\right): \delta 8.01\left(\mathrm{t},{ }^{3} J_{\mathrm{HH}}=7.7,1 \mathrm{H}, \mathrm{py}\right), 7.80$ $\left(\mathrm{d},{ }^{3} \mathrm{~J}_{\mathrm{HH}}=7.5,1 \mathrm{H}, \mathrm{biph}\right), 7.71-7.75\left(\mathrm{~m}, 8 \mathrm{H}, \mathrm{Ar}^{\mathrm{F}}\right), 7.70\left(\mathrm{~d},{ }^{3} \mathrm{~J}_{\mathrm{HH}}=7.7\right.$, $1 \mathrm{H}, \mathrm{py}), 7.58\left(\mathrm{~d},{ }^{3} J_{\mathrm{HH}}=7.7,1 \mathrm{H}, \mathrm{py}\right), 7.56\left(\mathrm{br}, \mathrm{Ar}^{\mathrm{F}}\right), 7.53\left(\mathrm{~d},{ }^{3} \mathrm{~J}_{\mathrm{HH}}=\right.$ 7.5, 1H, biph), $7.37\left(\mathrm{~d},{ }^{3} \mathrm{~J}_{\mathrm{HH}}=7.6,1 \mathrm{H}, \mathrm{biph}\right), 7.23(\mathrm{br}, 1 \mathrm{H}, \mathrm{NCH})$, $7.13\left(\mathrm{t},{ }^{3} J_{\mathrm{HH}}=7.4,1 \mathrm{H}, \mathrm{biph}\right), 7.06\left(\mathrm{t},{ }^{3} J_{\mathrm{HH}}=7.3,1 \mathrm{H}, \mathrm{biph}\right), 6.93(\mathrm{t}$, $\left.{ }^{3} J_{\mathrm{HH}}=7.4,1 \mathrm{H}, \mathrm{biph}\right), 6.91(\mathrm{br}, 1 \mathrm{H}, \mathrm{NCH}), 6.80(\mathrm{br}, 1 \mathrm{H}, \mathrm{NCH}), 6.78$ (br, $1 \mathrm{H}, \mathrm{NCH}), 6.41\left(\mathrm{t},{ }^{3} J_{\mathrm{HH}}=7.7,1 \mathrm{H}, \mathrm{biph}\right), 5.60\left(\mathrm{dd},{ }^{3} J_{\mathrm{HH}}=7.8\right.$, $1 \mathrm{H}, \mathrm{biph}), 5.49\left(\mathrm{~d},{ }^{2} J_{\mathrm{HH}}=15.6,1 \mathrm{H}, \mathrm{pyCH}\right), 5.28\left(\mathrm{~d},{ }^{2} J_{\mathrm{HH}}=15.6\right.$, $\left.1 \mathrm{H}, \mathrm{pyCH}_{2}\right), 5.25\left(\mathrm{~d},{ }^{2} J_{\mathrm{HH}}=15.6,1 \mathrm{H}, \mathrm{pyCH}_{2}\right), 4.81-4.85\left(\mathrm{ddd},{ }^{2} J_{\mathrm{HH}}\right.$ $\left.=13.9,{ }^{3} J_{\mathrm{HH}}=11.2,5.9,1 \mathrm{H}, \mathrm{NCH}_{2}\right), 4.80\left(\mathrm{~d},{ }^{2} J_{\mathrm{HH}}=15.6,1 \mathrm{H}\right.$, pyCH $\left.{ }_{2}\right), 3.65\left(\mathrm{dd}^{2} J_{\mathrm{HH}}=13.6,{ }^{3} J_{\mathrm{HH}}=6.1,1 \mathrm{H}, \mathrm{NCH}_{2}\right), 2.98(\mathrm{ddd}$, $\left.{ }^{2} J_{\mathrm{HH}}=14.5,{ }^{3} J_{\mathrm{HH}}=10.7,4.4,1 \mathrm{H}, \mathrm{NCH}_{2}\right), 2.58\left(\mathrm{dt},{ }^{2} J_{\mathrm{HH}}=13.8,{ }^{3} J_{\mathrm{HH}}\right.$ $\left.=4.2,1 \mathrm{H}, \mathrm{NCH}_{2}\right), 1.84-1.97\left(\mathrm{~m}, 1 \mathrm{H}, \mathrm{CH}_{2}\right), 0.97-1.70(\mathrm{~m}, 15 \mathrm{H}$, $\left.\mathrm{CH}_{2}\right), 0.77-0.96\left(\mathrm{~m}, 2 \mathrm{H}, \mathrm{CH}_{2}\right), 0.34-0.47\left(\mathrm{~m}, 1 \mathrm{H}, \mathrm{CH}_{2}\right), 0.24-0.34$ $\left(\mathrm{m}, 1 \mathrm{H}, \mathrm{CH}_{2}\right) .{ }^{13} \mathrm{C}\left\{{ }^{1} \mathrm{H}\right\} \mathrm{NMR}\left(126 \mathrm{MHz}, \mathrm{CD}_{2} \mathrm{Cl}_{2}\right): \delta 176.0\left(\mathrm{~d},{ }^{1} J_{\mathrm{RhC}}\right.$ $=44, \mathrm{NCN}), 174.5\left(\mathrm{~d},{ }^{1} J_{\mathrm{RhC}}=42, \mathrm{NCN}\right), 163.8\left(\mathrm{~d},{ }^{1} J_{\mathrm{RhC}}=38\right.$, biph $)$, $162.3\left(\mathrm{q},{ }^{1} J_{\mathrm{BC}}=50, \operatorname{Ar}^{\mathrm{F}}\right), 157.1(\mathrm{~s}, \mathrm{py}), 156.5(\mathrm{~s}, \mathrm{py}), 155.7\left(\mathrm{~d},{ }_{1}^{1} J_{\mathrm{RhC}}=\right.$ 45, biph), $152.9\left(\mathrm{~d},{ }^{2} J_{\mathrm{RhC}}=3\right.$, biph), $151.7\left(\mathrm{~d},{ }^{2} J_{\mathrm{RhC}}=4\right.$, biph $), 141.2$ (s, py), $138.5\left(\mathrm{~s}\right.$, biph), $135.4\left(\mathrm{~s}, \mathrm{Ar}^{\mathrm{F}}\right), 132.8(\mathrm{~s}, \mathrm{biph}), 129.4\left(\mathrm{qq},{ }^{2} J_{\mathrm{FC}}\right.$ $\left.=32,{ }^{3} J_{\mathrm{BC}}=3, \mathrm{Ar}^{\mathrm{F}}\right), 126.5(\mathrm{~s}, \mathrm{py}), 125.6\left(\mathrm{~d},{ }^{3} J_{\mathrm{RhC}}=2, \mathrm{biph}\right), 125.4(\mathrm{~d}$ $\left.{ }^{3} J_{\mathrm{RhC}}=1, \mathrm{biph}\right), 125.2\left(\mathrm{q},{ }^{1} J_{\mathrm{FC}}=272, \mathrm{Ar}^{\mathrm{F}}\right), 125.1(\mathrm{~s}, \mathrm{py}), 124.1(\mathrm{~s}$, biph), 124.0 (s, biph), 122.8 (s, NCH), 122.6 (s, NCH), 122.4 (s, $\mathrm{NCH}), 122.2(\mathrm{~s}, \mathrm{NCH}), 121.5\left(\mathrm{~d},{ }^{3} J_{\mathrm{RhC}}=3\right.$, biph $), 121.4\left(\mathrm{~d},{ }^{3} J_{\mathrm{RhC}}=\right.$ 2, biph), $118.0\left(\mathrm{sept}^{3} \mathrm{~J}_{\mathrm{FC}}=4, \mathrm{Ar}^{\mathrm{F}}\right), 56.1\left(\mathrm{~s}, \mathrm{pyCH}_{2}\right), 55.9\left(\mathrm{~s}, \mathrm{pyCH}_{2}\right)$, $49.4\left(\mathrm{~s}, \mathrm{NCH}_{2}\right), 47.8\left(\mathrm{~s}, \mathrm{NCH}_{2}\right), 30.6\left(\mathrm{~s}, \mathrm{CH}_{2}\right), 29.3\left(\mathrm{~s}, \mathrm{CH}_{2}\right), 28.7$ $\left(\mathrm{s}, \mathrm{CH}_{2}\right), 28.5\left(\mathrm{~s}, \mathrm{CH}_{2}\right), 27.7\left(\mathrm{CH}_{2}\right), 27.14\left(\mathrm{~s}, \mathrm{CH}_{2}\right), 27.08\left(\mathrm{~s}, \mathrm{CH}_{2}\right)$, $26.7\left(\mathrm{~s}, \mathrm{CH}_{2}\right), 25.3\left(\mathrm{~s}, \mathrm{CH}_{2}\right), 22.2\left(\mathrm{~s}, \mathrm{CH}_{2}\right)$. IR (ATR): $\nu(\mathrm{CH}) 3056$, 2934, 2859, $2682 \mathrm{~cm}^{-1}$. IR $\left(\mathrm{CCl}_{4}\right): \nu(\mathrm{CH}) 3053,2978,2928,2859$, $2694 \mathrm{~cm}^{-1}$. Anal. Calcd for $\mathrm{C}_{69} \mathrm{H}_{55} \mathrm{BF}_{24} \mathrm{~N}_{5} \mathrm{Rh}\left(1523.91 \mathrm{~g} \mathrm{~mol}^{-1}\right)$ : C, 54.38; H, 3.64; N, 4.60. Calcd for $\mathrm{C}_{69} \mathrm{H}_{55} \mathrm{BF}_{24} \mathrm{~N}_{5} \mathrm{Rh} \cdot \mathrm{C}_{1.5} \mathrm{H}_{3} \mathrm{Cl}_{3}$ $\left(1657.31 \mathrm{~g} \mathrm{~mol}^{-1}\right)$ : C, 51.28; H, 3.54; N, 4.24. Found: C, 51.17; $\mathrm{H}, 3.66$; N, 4.15. HR ESI-MS (positive ion, $4 \mathrm{kV}): 660.2566\left([\mathrm{M}]^{+}\right.$, calcd 660.2568$) \mathrm{m} / z$.

[Rh(CNC-12)(biph)(CO)][BAr $\left.{ }_{4}\right]$ (3a). A solution of $[\mathrm{Rh}(\mathrm{CNC}-$ 12) $(\mathrm{biph})]\left[\mathrm{BAr}_{4}^{\mathrm{F}}\right](1 \mathrm{a} ; 45.7 \mathrm{mg}, 30.0 \mu \mathrm{mol})$ in $\mathrm{CH}_{2} \mathrm{Cl}_{2}($ ca. $1 \mathrm{~mL})$ was freeze-pump-thaw degassed and placed under an atmosphere of $\mathrm{CO}$ to immediately afford a colorless solution. The volatiles were removed in vacuo, and the product recrystallized from $\mathrm{CH}_{2} \mathrm{Cl}_{2}$ / hexane $(1 / 15$, ca. $15 \mathrm{~mL})$ to afford the product as pale yellow blocks, which were isolated through decantation of the supernatant and dried in vacuo. Yield: $39.9 \mathrm{mg}$ (86\%). Single crystals suitable for X-ray 
diffraction were obtained by slow diffusion of hexane into a solution in $\mathrm{CH}_{2} \mathrm{Cl}_{2}$ at ambient temperature.

${ }^{1} \mathrm{H}$ NMR (500 MHz, $\left.\mathrm{CD}_{2} \mathrm{Cl}_{2}\right): \delta 8.04\left(\mathrm{t},{ }^{3} J_{\mathrm{HH}}=7.7,1 \mathrm{H}, \mathrm{py}\right), 8.00$ $\left(\mathrm{d},{ }^{3} J_{\mathrm{HH}}=7.5,1 \mathrm{H}, \mathrm{biph}\right), 7.71-7.78\left(\mathrm{~m}, 8 \mathrm{H}, \mathrm{Ar}^{\mathrm{F}}\right), 7.65(\mathrm{vbr}, \mathrm{fwhm}=$ $50 \mathrm{~Hz}, 2 \mathrm{H}, \mathrm{py}), 7.57\left(\mathrm{br}, 4 \mathrm{H}, \mathrm{Ar}^{\mathrm{F}}\right), 7.55\left(\mathrm{~d},{ }^{3} J_{\mathrm{HH}}=7.7,1 \mathrm{H}, \mathrm{biph}\right)$, $7.52\left(\mathrm{~d},{ }^{3} \mathrm{~J}_{\mathrm{HH}}=7.7,1 \mathrm{H}, \mathrm{biph}\right), 7.23$ (obscured vbr, $\left.1 \mathrm{H} \mathrm{NCH}\right), 7.17(\mathrm{t}$, $\left.{ }^{3} J_{\mathrm{HH}}=7.4,1 \mathrm{H}, \mathrm{biph}\right), 7.10\left(\mathrm{t},{ }^{3} \mathrm{~J}_{\mathrm{HH}}=7.4,1 \mathrm{H}, \mathrm{biph}\right), 7.0$ (obscured vbr, $1 \mathrm{H} \mathrm{NCH}), 6.98\left(\mathrm{t},{ }^{3} \mathrm{~J}_{\mathrm{HH}}=7.4,1 \mathrm{H}, \mathrm{biph}\right), 6.84$ (vbr, fhwm $=20$ $\mathrm{Hz}, 2 \mathrm{H}, \mathrm{NCH}), 6.51\left(\mathrm{t},{ }^{3} J_{\mathrm{HH}}=7.4,1 \mathrm{H}, \mathrm{biph}\right), 5.76\left(\mathrm{~d},{ }^{3} J_{\mathrm{HH}}=7.6,1 \mathrm{H}\right.$, biph), $5.37\left(\mathrm{~d},{ }^{2} J_{\mathrm{HH}}=14.8,2 \mathrm{H}, \mathrm{pyCH}_{2}\right), 5.17(\mathrm{vbr}, \mathrm{fwhm}=120 \mathrm{~Hz}$, $\left.2 \mathrm{H}, \mathrm{pyCH}_{2}+\mathrm{NCH}_{2}\right), 4.80\left(\mathrm{vbr}, \mathrm{fwhm}=70 \mathrm{~Hz}, 1 \mathrm{H}, \mathrm{pyCH}_{2}\right), 2.88-$ $3.44\left(\mathrm{~m}, 3 \mathrm{H}, \mathrm{NCH}_{2}\right), 1.00-2.09\left(\mathrm{~m}, 18 \mathrm{H}, \mathrm{CH}_{2}\right), 0.79\left(\mathrm{br}, 1 \mathrm{H}, \mathrm{CH}_{2}\right)$, $0.55\left(\mathrm{br}, 1 \mathrm{H}, \mathrm{CH}_{2}\right) .{ }^{13} \mathrm{C}\left\{{ }^{1} \mathrm{H}\right\} \mathrm{NMR}\left(126 \mathrm{MHz}, \mathrm{CD}_{2} \mathrm{Cl}_{2}\right): \delta 187.6(\mathrm{~d}$, $\left.{ }^{1} J_{\mathrm{RhC}}=41, \mathrm{RhCO}\right), 168.0(\mathrm{br}, \mathrm{NCN}), 166.0\left(\mathrm{~d},{ }^{1} J_{\mathrm{RhC}}=27, \mathrm{biph}\right)$, $165.6(\mathrm{br}, \mathrm{NCN}), 162.4\left(\mathrm{q},{ }^{1} J_{\mathrm{BC}}=50, \operatorname{Ar}^{\mathrm{F}}\right), 158.3\left(\mathrm{~d},{ }^{1} J_{\mathrm{RhC}}=34\right.$, biph), 156.6 (br, py), 155.7 (br, py), 155.0 (d, ${ }^{2} J_{\mathrm{RhC}}=3$, biph), 153.0 $\left(\mathrm{d},{ }^{2} J_{\mathrm{RhC}}=3\right.$, biph), 143.1 (s, biph), $141.5(\mathrm{~s}, \mathrm{py}), 135.4\left(\mathrm{~s}, \mathrm{Ar}^{\mathrm{F}}\right)$, 134.9 (s, biph), $129.5\left(\mathrm{qq},{ }^{2} J_{\mathrm{FC}}=32,{ }^{3} J_{\mathrm{BC}}=3, \mathrm{Ar}^{\mathrm{F}}\right), 126.6(\mathrm{br}, \mathrm{py})$, 125.7 (s, biph), $125.4\left(\mathrm{~d},{ }^{3} J_{\mathrm{RhC}}=2\right.$, biph $), 125.2\left(\mathrm{q},{ }^{1} J_{\mathrm{FC}}=272, \mathrm{Ar}^{\mathrm{F}}\right)$, 124.9 (s, biph), 124.8 (s, biph), 123.7 (br, NCH), 122.1 (br, NCH), 122.1 (biph), 121.8 (biph), $118.1\left(\mathrm{sept},{ }^{3} J_{\mathrm{FC}}=4, \mathrm{Ar}^{\mathrm{F}}\right), 57.3(\mathrm{br}$, pyCH $\mathrm{CH}_{2}$ ), 56.2 (br, pyCH $\mathrm{CH}_{2}$ ), $50.1\left(\mathrm{br}, \mathrm{NCH}_{2}\right), 46.8\left(\mathrm{br}, \mathrm{NCH}_{2}\right), 29.2$ (br, $\mathrm{CH}_{2}$ ), 28.9 (br, $\mathrm{CH}_{2}$ ), 28.7 (br, $\left.\mathrm{CH}_{2}\right), 28.4\left(\mathrm{br}, \mathrm{CH}_{2}\right)$. IR (ATR): $\nu(\mathrm{CH}) 3063,2940,2859 ; \nu(\mathrm{CO}) 2065 \mathrm{~cm}^{-1}$. IR $\left(\mathrm{CCl}_{4}\right): \nu(\mathrm{CH})$ 3054, 2960, 2932, 2859; $\nu$ (CO) $2054 \mathrm{~cm}^{-1}$. IR $\left(\mathrm{CH}_{2} \mathrm{Cl}_{2}\right): \nu(\mathrm{CO})$ $2050 \mathrm{~cm}^{-1}$. Anal. Calcd for $\mathrm{C}_{70} \mathrm{H}_{55} \mathrm{BF}_{24} \mathrm{~N}_{5} \mathrm{ORh}\left(1551.92 \mathrm{~g} \mathrm{~mol}^{-1}\right)$ : C, 54.18; H, 3.57; N, 4.51. Found: C, 54.30; H, 3.76; N, 4.59. HR ESIMS (positive ion, $4 \mathrm{kV}): 660.2562\left([\mathrm{M}-\mathrm{CO}]^{+}\right.$, calcd 660.2568$) \mathrm{m} /$ $z$.

[Ir(CNC-12)(biph)][BAr $\left.{ }_{4}\right]$ (1b). A suspension of $[\operatorname{Ir}(\mathrm{biph}) \mathrm{Cl}-$ $(\mathrm{COD})]_{2}(76.6 \mathrm{mg}, 78.5 \mu \mathrm{mol})$ and $[\mathrm{Cu}(\mathrm{CNC}-12)]\left[\mathrm{BAr}^{\mathrm{F}}{ }_{4}\right](199.7$ mg, $149.9 \mu \mathrm{mol}$ ) in $\mathrm{CH}_{2} \mathrm{Cl}_{2}$ (ca. $3 \mathrm{~mL}$ ) was stirred at ambient temperature for $18 \mathrm{~h}$ and filtered and the precipitate washed with $\mathrm{CH}_{2} \mathrm{Cl}_{2}(3 \times 1 \mathrm{~mL})$. Volatiles were removed in vacuo, and the product recrystallized from $\mathrm{Et}_{2} \mathrm{O} /$ hexane $(1 / 20$, ca. $25 \mathrm{~mL})$ to afford the product as a mixture of yellow needles and red blocks. Yield: $186.4 \mathrm{mg}$ (77\%). Single crystals suitable for X-ray diffraction were obtained by slow diffusion of hexane into a solution in $\mathrm{CH}_{2} \mathrm{Cl}_{2}$ at ambient temperature.

${ }^{1} \mathrm{H}$ NMR $\left(500 \mathrm{MHz}, \mathrm{CD}_{2} \mathrm{Cl}_{2}\right): \delta 8.02\left(\mathrm{t},{ }^{3} J_{\mathrm{HH}}=7.7,1 \mathrm{H}, \mathrm{py}\right), 7.77$ $\left(\mathrm{d},{ }^{3} J_{\mathrm{HH}}=7.5,1 \mathrm{H}, \mathrm{biph}\right), 7.74\left(\mathrm{~d},{ }^{3} \mathrm{~J}_{\mathrm{HH}}=7.7,1 \mathrm{H}, \mathrm{py}\right), 7.70-7.75(\mathrm{~m}$, $\left.8 \mathrm{H}, \mathrm{Ar}^{\mathrm{F}}\right), 7.59\left(\mathrm{~d},{ }^{3} J_{\mathrm{HH}}=7.7,1 \mathrm{H}, \mathrm{py}\right), 7.56\left(\mathrm{br}, 4 \mathrm{H}, \operatorname{Ar}^{\mathrm{F}}\right), 7.52(\mathrm{~d}$, $\left.{ }^{3} J_{\mathrm{HH}}=7.6,1 \mathrm{H}, \mathrm{biph}\right), 7.31\left(\mathrm{~d},{ }^{3} J_{\mathrm{HH}}=7.6,1 \mathrm{H}, \mathrm{biph}\right), 7.23\left(\mathrm{~d},{ }^{3} \mathrm{~J}_{\mathrm{HH}}=\right.$ 1.9, $1 \mathrm{H}, \mathrm{NCH}), 7.07\left(\mathrm{t},{ }^{3} \mathrm{JHH}_{\mathrm{HH}}=7.4,1 \mathrm{H}, \mathrm{biph}\right), 7.00\left(\mathrm{t},{ }^{3} \mathrm{~J}_{\mathrm{HH}}=7.3,1 \mathrm{H}\right.$, biph), $6.90\left(\mathrm{~d},{ }^{3} J_{\mathrm{HH}}=1.9,1 \mathrm{H}, \mathrm{NCH}\right), 6.86\left(\mathrm{t},{ }^{3} \mathrm{~J}_{\mathrm{HH}}=7.4,1 \mathrm{H}, \mathrm{biph}\right)$, 6.84 (obscured, $1 \mathrm{H}, \mathrm{NCH}), 6.79\left(\mathrm{~d},{ }^{3} J_{\mathrm{HH}}=2.0,1 \mathrm{H}, \mathrm{NCH}\right), 6.29(\mathrm{t}$, $\left.{ }^{3} J_{\mathrm{HH}}=7.5,1 \mathrm{H}, \mathrm{biph}\right), 5.41\left(\mathrm{~d},{ }^{2} J_{\mathrm{HH}}=15.6,1 \mathrm{H}, \mathrm{pyCH}_{2}\right), 5.40\left(\mathrm{~d},{ }^{3} J_{\mathrm{HH}}\right.$ $=7.6,1 \mathrm{H}, \mathrm{biph}$ ), 5.24 (br coalesced $\mathrm{AB}$ doublets, $2 \mathrm{H}, \mathrm{pyCH}_{2}$ ), 4.90 $\left(\mathrm{ddd},{ }^{2} J_{\mathrm{HH}}=14.1,{ }^{3} J_{\mathrm{HH}}=11.5,{ }^{3} J_{\mathrm{HH}}=5.7,1 \mathrm{H}, \mathrm{NCH}_{2}\right), 4.72\left(\mathrm{~d},{ }^{2} J_{\mathrm{HH}}\right.$ $=15.6,1 \mathrm{H}, \mathrm{pyCH})_{2}, 3.63\left(\mathrm{ddd},{ }^{2} J_{\mathrm{HH}}=14.1,{ }^{3} J_{\mathrm{HH}}=6.8,2.1,1 \mathrm{H}\right.$, $\left.\mathrm{NCH}_{2}\right), 2.88\left(\mathrm{ddd},{ }^{2} J_{\mathrm{HH}}=14,{ }^{3} J_{\mathrm{HH}}=10.7,4.4,1 \mathrm{H}, \mathrm{NCH}_{2}\right), 2.46(\mathrm{dt}$, $\left.{ }^{2} J_{\mathrm{HH}}=14,{ }^{3} J_{\mathrm{HH}}=4.1,1 \mathrm{H}, \mathrm{NCH}_{2}\right), 1.97-2.10\left(\mathrm{~m}, 1 \mathrm{H}, \mathrm{CH}_{2}\right), 0.76-$ $1.80\left(\mathrm{~m}, 17 \mathrm{H}, \mathrm{CH}_{2}\right), 0.37-0.54\left(\mathrm{~m}, 1 \mathrm{H}, \mathrm{CH}_{2}\right),-0.73$ to $-0.60(\mathrm{~m}$, $\left.1 \mathrm{H}, \mathrm{CH}_{2}\right) .{ }^{13} \mathrm{C}\left\{{ }^{1} \mathrm{H}\right\}$ NMR $\left(126 \mathrm{MHz}, \mathrm{CD}_{2} \mathrm{Cl}_{2}\right): \delta 165.9(\mathrm{~s}, \mathrm{NCN})$, $163.3(\mathrm{~s}, \mathrm{NCN}), 162.3\left(\mathrm{q},{ }^{1} J_{\mathrm{BC}}=50, \mathrm{Ar}^{\mathrm{F}}\right), 157.8(\mathrm{~s}, \mathrm{py}), 156.9(\mathrm{~s}, \mathrm{py})$, 153.0 (s, biph), 152.7 (s, biph), 142.9 (s, biph), 141.1 (s, py), 139.2 (s, biph), $135.4\left(\mathrm{~s}, \operatorname{Ar}^{\mathrm{F}}\right), 130.6(\mathrm{~s}, \mathrm{biph}), 129.4\left(\mathrm{qq},{ }^{2} J_{\mathrm{FC}}=32,{ }^{3} J_{\mathrm{BC}}=\right.$ 3, $\operatorname{Ar}^{\mathrm{F}}$ ), 127.0 (s, py), 126.0 (s, biph), 125.6 (s, py),125.5 (s, biph), $125.2\left(\mathrm{q},{ }^{1} J_{\mathrm{FC}}=272, \mathrm{Ar}^{\mathrm{F}}\right), 125.1(\mathrm{~s}, \mathrm{biph}), 123.9(\mathrm{~s}, \mathrm{biph}), 123.4(\mathrm{~s}$, biph), $122.7(\mathrm{~s}, 2 \times \mathrm{NCH}), 122.0(\mathrm{~s}, \mathrm{NCH}), 121.9(\mathrm{~s}, \mathrm{NCH}), 121.4$ (s, biph), $120.8(\mathrm{~s}$, biph $), 118.0\left(\mathrm{sept},{ }^{3} J_{\mathrm{FC}}=4, \mathrm{Ar}^{\mathrm{F}}\right), 57.3\left(\mathrm{~s}, \mathrm{pyCH}_{2}\right)$, $56.6\left(\mathrm{~s}, \mathrm{pyCH}_{2}\right), 49.6\left(\mathrm{~s}, \mathrm{NCH}_{2}\right), 47.5\left(\mathrm{~s}, \mathrm{NCH}_{2}\right), 30.2\left(\mathrm{~s}, \mathrm{CH}_{2}\right), 29.7$ $\left(\mathrm{s}, \mathrm{CH}_{2}\right), 28.4\left(\mathrm{~s}, \mathrm{CH}_{2}\right), 28.3\left(\mathrm{~s}, \mathrm{CH}_{2}\right), 27.4\left(\mathrm{~s}, \mathrm{CH}_{2}\right), 26.9(\mathrm{~s}, 2 \times$ $\left.\mathrm{CH}_{2}\right), 26.7\left(\mathrm{~s}, \mathrm{CH}_{2}\right), 25.1\left(\mathrm{~s}, \mathrm{CH}_{2}\right), 21.7\left(\mathrm{~s}, \mathrm{CH}_{2}\right)$. IR (ATR): $\nu(\mathrm{CH})$ 3059, 2933, 2861, $2571 \mathrm{~cm}^{-1}$. IR $\left(\mathrm{CCl}_{4}\right): \nu(\mathrm{CH}) 3056,2930,2860$, $2577 \mathrm{~cm}^{-1}$. Anal. Calcd for $\mathrm{C}_{69} \mathrm{H}_{55} \mathrm{BF}_{24} \mathrm{IrN}_{5}\left(1613.22 \mathrm{~g} \mathrm{~mol}^{-1}\right)$ : C, 51.37; H, 3.44; N, 4.34. Found: C, 51.26; H, 3.19; N, 4.35. HR ESIMS (positive ion, $4 \mathrm{kV}): 750.3138\left([\mathrm{M}]^{+}\right.$, calcd 750.3144) $\mathrm{m} / \mathrm{z}$.
[ $\operatorname{lr}(\mathrm{CNC}-12)(\mathrm{biph})(\mathrm{CO})]\left[\mathrm{BAr}_{4}{ }_{4}\right]$ (3b). A solution of $[\mathrm{Ir}(\mathrm{CNC}$ 12) (biph)] $\left[\mathrm{BAr}_{4}^{\mathrm{F}}\right](\mathbf{1 b} ; 45.7 \mathrm{mg}, 30.0 \mu \mathrm{mol})$ in $\mathrm{CH}_{2} \mathrm{Cl}_{2}($ ca. $1 \mathrm{~mL})$ was freeze-pump-thaw degassed and placed under an atmosphere of $\mathrm{CO}$ to immediately afford a colorless solution. The volatiles were removed in vacuo, and the product recrystallized from $\mathrm{CH}_{2} \mathrm{Cl}_{2}$ / hexane $(1 / 15$, ca. $15 \mathrm{~mL})$ to afford the title compound as colorless blocks, which were isolated through decantation of the supernatant and dried in vacuo. Yield: $41.7 \mathrm{mg}$ (85\%). Single crystals suitable for $\mathrm{X}$-ray diffraction were obtained by slow diffusion of hexane into a solution in $\mathrm{CH}_{2} \mathrm{Cl}_{2}$ at ambient temperature.

${ }^{1} \mathrm{H}$ NMR $\left(500 \mathrm{MHz}, \mathrm{CD}_{2} \mathrm{Cl}_{2}\right): \delta 8.08\left(\mathrm{t},{ }^{3} J_{\mathrm{HH}}=7.8,1 \mathrm{H}, \mathrm{py}\right), 8.05$ $\left(\mathrm{d},{ }^{3} \mathrm{~J}_{\mathrm{HH}}=7.5,1 \mathrm{H}, \mathrm{biph}\right), 7.76$ (obscured, $\left.1 \mathrm{H}, \mathrm{py}\right), 7.70-7.76(\mathrm{~m}, 8 \mathrm{H}$, $\left.\mathrm{Ar}^{\mathrm{F}}\right), 7.63\left(\mathrm{br},{ }^{3} \mathrm{~J}_{\mathrm{HH}}=7.6,1 \mathrm{H}, \mathrm{py}\right), 7.54-7.58\left(\mathrm{~m}, 6 \mathrm{H}, \mathrm{Ar}^{\mathrm{F}}+2 \times\right.$ biph), $7.24(\mathrm{br}, 1 \mathrm{H}, \mathrm{NCH}), 7.13\left(\mathrm{t},{ }^{3} J_{\mathrm{HH}}=7.4,1 \mathrm{H}, \mathrm{biph}\right), 7.05(\mathrm{t}$, $\left.{ }^{3} J_{\mathrm{HH}}=7.3,1 \mathrm{H}, \mathrm{biph}\right), 6.99\left(\mathrm{t}^{3} \mathrm{~J}_{\mathrm{HH}}=7.4,1 \mathrm{H}, \mathrm{biph}\right), 6.94(\mathrm{br}, 1 \mathrm{H}$, $\mathrm{NCH}), 6.89(\mathrm{br}, 1 \mathrm{H}, \mathrm{NCH}), 6.79(\mathrm{br}, 1 \mathrm{H}, \mathrm{NCH}), 6.55\left(\mathrm{t},{ }^{3} \mathrm{~J}_{\mathrm{HH}}=7.3\right.$, $1 \mathrm{H}$, biph), $5.86\left(\mathrm{~d},{ }^{3} J_{\mathrm{HH}}=7.5,1 \mathrm{H}, \mathrm{biph}\right), 5.41\left(\mathrm{~d},{ }^{2} J_{\mathrm{HH}}=16.0,1 \mathrm{H}\right.$, pyCH $\left.\left.\mathrm{H}_{2}\right), 5.34(\mathrm{br}, 2 \mathrm{H}, \mathrm{pyCH})_{2}\right), 5.14-5.26\left(\mathrm{~m}, 1 \mathrm{H}, \mathrm{NCH}_{2}\right), 4.78(\mathrm{~d}$, $\left.{ }^{2} J_{\mathrm{HH}}=16.0,1 \mathrm{H}, \mathrm{pyCH}_{2}\right), 3.05-3.22\left(\mathrm{~m}, 2 \mathrm{H}, \mathrm{NCH}_{2}\right), 2.87-3.04(\mathrm{~m}$, $\left.1 \mathrm{H}, \mathrm{NCH}_{2}\right), 1.18-1.99\left(\mathrm{~m}, 18 \mathrm{H}, \mathrm{CH}_{2}\right), 0.73\left(\mathrm{br}, 1 \mathrm{H}, \mathrm{CH}_{2}\right), 0.51(\mathrm{br}$, $\left.1 \mathrm{H}, \mathrm{CH}_{2}\right) \cdot{ }^{13} \mathrm{C}\left\{{ }^{1} \mathrm{H}\right\}$ NMR $\left(126 \mathrm{MHz}, \mathrm{CD}_{2} \mathrm{Cl}_{2}\right): \delta 174.2$ (s, IrCO), $162.3\left(\mathrm{q},{ }^{1} J_{\mathrm{BC}}=50, \mathrm{Ar}^{\mathrm{F}}\right), 156.4(\mathrm{br}, \mathrm{py}), 156.2(\mathrm{br}, \mathrm{py}), 154.5(\mathrm{~s}$, biph), 153.8 (s, biph), 152.8 (s, biph), 150.3 (br, NCN), 147.6 (br, NCN), 142.9 (s, biph), 141.9 (s, py), 135.9 (s, biph), $135.4\left(\mathrm{~s}, \mathrm{Ar}^{\mathrm{F}}\right)$, 134.8 (s, biph), $129.4\left(\mathrm{qq},{ }^{2} J_{\mathrm{FC}}=32,{ }^{3} J_{\mathrm{BC}}=3, \mathrm{Ar}^{\mathrm{F}}\right), 128.0$ (s, py), 126.12 (br, py), 126.07 (s, biph), 125.9 (s, biph), $125.2\left(\mathrm{q},{ }^{1} J_{\mathrm{FC}}=\right.$ 272, $\left.\mathrm{Ar}^{\mathrm{F}}\right), 125.0$ (s, biph), 124.6 (s, biph), 123.2 (br, NCH), 123.1 (br, NCH), 122.7 (br, NCH), 122.3 (br, NCH), 122.1 (s, biph), 122.0 (s, biph), $118.1\left(\mathrm{sept},{ }^{3} J_{\mathrm{FC}}=4, \mathrm{Ar}^{\mathrm{F}}\right), 58.9\left(\mathrm{~s}, \mathrm{pyCH}_{2}\right), 56.8(\mathrm{~s}$, $\left.\mathrm{pyCH}_{2}\right), 50.2\left(\mathrm{~s}, \mathrm{NCH}_{2}\right), 46.5\left(\mathrm{~s}, \mathrm{NCH}_{2}\right), 29.4\left(\mathrm{~s}, \mathrm{CH}_{2}\right), 29.0(\mathrm{~s}$, $\left.\mathrm{CH}_{2}\right), 28.9\left(\mathrm{~s}, \mathrm{CH}_{2}\right), 28.6\left(3 \times \mathrm{CH}_{2}\right), 28.5\left(\mathrm{~s}, \mathrm{CH}_{2}\right), 28.1\left(\mathrm{~s}, \mathrm{CH}_{2}\right)$, $26.5\left(\mathrm{~s}, \mathrm{CH}_{2}\right), 23.4\left(\mathrm{~s}, \mathrm{CH}_{2}\right)$. IR (ATR): $\nu(\mathrm{CH}) 3063,2940,2860$; $\nu(\mathrm{CO}) 2034 \mathrm{~cm}^{-1}$. IR $\left(\mathrm{CCl}_{4}\right): \nu(\mathrm{CH}) 3055,2932,2858 ; \nu(\mathrm{CO})$ $2022 \mathrm{~cm}^{-1}$. IR $\left(\mathrm{CH}_{2} \mathrm{Cl}_{2}\right): \nu(\mathrm{CO}) 2018 \mathrm{~cm}^{-1}$. Anal. Calcd for $\mathrm{C}_{70} \mathrm{H}_{55} \mathrm{BF}_{24} \mathrm{IrN}_{5} \mathrm{O}\left(1641.23 \mathrm{~g} \mathrm{~mol}^{-1}\right)$ : C, 51.23; H, 3.38; N, 4.27. Found: C, 51.35; H, 3.37; N, 4.42. HR ESI-MS (positive ion, $4 \mathrm{kV}$ ): $778.3083\left([M]^{+}\right.$, calcd 778.3069$) \mathrm{m} / z$.

Crossover Experiment. A solution of $[\mathrm{Rh}(\mathrm{CNC}-12)(\mathrm{biph})-$ (CO) $]\left[\mathrm{BAr}_{4}^{\mathrm{F}}\right.$ ] 3a $(15.4 \mathrm{mg}, 9.92 \mu \mathrm{mol})$ and $[\operatorname{Ir}(\mathrm{CNC}-12)(\mathrm{biph})]$ $\left[\mathrm{BAr}^{\mathrm{F}}{ }_{4}\right] \mathbf{1 b}(16.0 \mathrm{mg}, 9.92 \mu \mathrm{mol})$ in $1,2-\mathrm{C}_{6} \mathrm{H}_{4} \mathrm{~F}_{2}$ (ca. $\left.0.5 \mathrm{~mL}\right)$ was heated at $90{ }^{\circ} \mathrm{C}$ for $18 \mathrm{~h}$. Analysis by ${ }^{1} \mathrm{H}$ NMR spectroscopy and LR ESI-MS indicated formation of a 1:1 mixture of $[\mathrm{Rh}(\mathrm{CNC}$ 12) (biph) $]\left[\mathrm{BAr}_{4}^{\mathrm{F}}\right]$ 1a and $[\operatorname{Ir}(\mathrm{CNC}-12)(\mathrm{biph})(\mathrm{CO})]\left[\mathrm{BAr}^{\mathrm{F}}\right] \mathbf{3 b}$.

$\left[\mathrm{Rh}(\mathrm{CNC}-12) \mathrm{H}_{2}\right]\left[\mathrm{BAr}_{4}\right]$ (2a). A solution of $[\mathrm{Rh}(\mathrm{CNC}-12)$ (biph)][BAr $\left.{ }_{4}{ }^{\mathrm{F}}\right](\mathbf{1}$; $30.6 \mathrm{mg}, 20.1 \mu \mathrm{mol})$ in $\mathrm{CD}_{2} \mathrm{Cl}_{2}$ (ca. $0.5 \mathrm{~mL}$ ) was freeze-pump-thaw degassed and placed under an atmosphere of dihydrogen. The solution was mixed for $6 \mathrm{~h}$ at ambient temperature to afford the product quantitatively by NMR spectroscopy.

${ }^{1} \mathrm{H}$ NMR (500 MHz, $\mathrm{CD}_{2} \mathrm{Cl}_{2} / \mathrm{H}_{2}$, signals for biphenyl omitted): $\delta$ $7.89\left(\mathrm{t},{ }^{3} J_{\mathrm{HH}}=7.7,1 \mathrm{H}, \mathrm{py}\right), 7.68-7.78\left(\mathrm{~m}, 8 \mathrm{H}, \mathrm{Ar}^{\mathrm{F}}\right), 7.57(\mathrm{~s}, 4 \mathrm{H}$, $\left.\operatorname{Ar}^{\mathrm{F}}\right), 7.52\left(\mathrm{~d},{ }^{3} \mathrm{~J}_{\mathrm{HH}}=7.7,2 \mathrm{H}, \mathrm{py}\right), 7.16(\mathrm{br}, 2 \mathrm{H}, \mathrm{NCH}), 7.04(\mathrm{br}, 2 \mathrm{H}$, $\mathrm{NCH}$ ), $\left.5.22(\mathrm{br}, 4 \mathrm{H}, \mathrm{pyCH})_{2}\right), 4.20\left(\mathrm{br}, 4 \mathrm{H}, \mathrm{NCH}_{2}\right), 1.72-1.96(\mathrm{~m}$, $\left.4 \mathrm{H}, \mathrm{CH}_{2}\right), 0.99-1.65\left(\mathrm{~m}, 16 \mathrm{H}, \mathrm{CH}_{2}\right),-18.87(\mathrm{br}, \mathrm{fwhm}=150 \mathrm{~Hz}$, $\left.T_{1}=643 \pm 19 \mathrm{~ms}, 2 \mathrm{H}, \mathrm{RhH}\right) .{ }^{1} \mathrm{H}$ NMR $\left(500 \mathrm{MHz}, \mathrm{CD}_{2} \mathrm{Cl}_{2} / \mathrm{H}_{2}, 200\right.$ $\mathrm{K}$, selected data): $\delta-18.66\left(\mathrm{br}, \mathrm{fwhm}=130 \mathrm{~Hz}, \mathrm{~T}_{1}=494 \pm 32 \mathrm{~ms}\right.$, $2 \mathrm{H}, \mathrm{RhH})$.

The resulting yellow solution was freeze-pump-thaw degassed, placed under argon, and characterized in situ using ${ }^{1} \mathrm{H}$ and ${ }^{13} \mathrm{C}$ NMR spectroscopy. The resulting solution was layered with excess hexane and stored at $-30{ }^{\circ} \mathrm{C}$ to afford a red gum consistent with the title compound as the major species, but in low purity (Figure S34).

${ }^{1} \mathrm{H}$ NMR ( $500 \mathrm{MHz}, \mathrm{CD}_{2} \mathrm{Cl}_{2}$, signals for biphenyl omitted): $\delta 7.88$ $\left(\mathrm{t},{ }^{3} J_{\mathrm{HH}}=7.8,1 \mathrm{H}, \mathrm{py}\right), 7.71-7.77\left(\mathrm{~m}, 8 \mathrm{H}, \mathrm{Ar}^{\mathrm{F}}\right), 7.57\left(\mathrm{~s}, 4 \mathrm{H}, \mathrm{Ar}^{\mathrm{F}}\right)$, $7.52\left(\mathrm{~d},{ }^{3} J_{\mathrm{HH}}=7.8,2 \mathrm{H}, \mathrm{py}\right), 7.17(\mathrm{br}, 2 \mathrm{H}, \mathrm{NCH}), 7.04(\mathrm{br}, 2 \mathrm{H}$, $\mathrm{NCH}), 5.22\left(\right.$ br, $4 \mathrm{H}, \mathrm{pyCH}$ ), $4.19\left(\mathrm{br}, 4 \mathrm{H}, \mathrm{NCH}_{2}\right), 1.77-1.91(\mathrm{~m}$, $\left.4 \mathrm{H}, \mathrm{CH}_{2}\right), 1.18-1.51\left(\mathrm{~m}, 16 \mathrm{H}, \mathrm{CH}_{2}\right),-18.89\left(\mathrm{~d},{ }^{1} J_{\mathrm{RhH}}=40.6, T_{1}=\right.$ $754 \pm 23 \mathrm{~ms}, 2 \mathrm{H}, \mathrm{RhH}) \cdot{ }^{13} \mathrm{C}\left\{{ }^{1} \mathrm{H}\right\} \mathrm{NMR}\left(126 \mathrm{MHz}, \mathrm{CD}_{2} \mathrm{Cl}_{2}\right.$, signals for biphenyl omitted): $\delta 182.8\left(\mathrm{~d},{ }^{1} J_{\mathrm{RhC}}=40 \mathrm{~Hz}, \mathrm{NCN}\right), 162.3(\mathrm{q}$, $\left.{ }^{1} J_{\mathrm{BC}}=50, \mathrm{Ar}^{\mathrm{F}}\right), 156.3(\mathrm{~s}, \mathrm{py}), 140.0(\mathrm{~s}, \mathrm{py}), 135.3\left(\mathrm{~s}, \mathrm{Ar}^{\mathrm{F}}\right), 129.4(\mathrm{qq}$, $\left.{ }^{2} J_{\mathrm{FC}}=32,{ }^{3} J_{\mathrm{BC}}=3, \mathrm{Ar}^{\mathrm{F}}\right), 125.18(\mathrm{~s}, \mathrm{py}), 125.17\left(\mathrm{q},{ }^{1} J_{\mathrm{FC}}=272, \mathrm{Ar}^{\mathrm{F}}\right)$, 
$122.5(\mathrm{NCH}), 120.6(\mathrm{NCH}), 118.1\left(\mathrm{sept},{ }^{3} \mathrm{JC}_{\mathrm{FC}}=4, \mathrm{Ar}^{\mathrm{F}}\right), 56.3(\mathrm{~s}$, pyCH $\left.\mathrm{CH}_{2}\right), 51.5\left(\mathrm{~s}, \mathrm{NCH}_{2}\right), 30.8\left(\mathrm{~s}, \mathrm{CH}_{2}\right), 27.8\left(\mathrm{~s}, \mathrm{CH}_{2}\right), 27.6\left(\mathrm{~s}, \mathrm{CH}_{2}\right)$, $26.8\left(\mathrm{~s}, \mathrm{CH}_{2}\right), 25.6\left(\mathrm{~s}, \mathrm{CH}_{2}\right)$.

[Rh(CNC-12)(CO)][BArF $\left.{ }_{4}\right]$ (B). A solution of $[\mathrm{Rh}(\mathrm{CNC}-12)$ (biph)][BAr ${ }_{4}^{\mathrm{F}}$ ] $(\mathbf{1 a} ; 15.4 \mathrm{mg}, 10.1 \mu \mathrm{mol})$ in $\mathrm{CD}_{2} \mathrm{Cl}_{2}$ (ca. $0.3 \mathrm{~mL}$ ) was freeze-pump-thaw degassed and placed under an atmosphere of dihydrogen. After mixing for $6 \mathrm{~h}$ at ambient temperature, the resulting pale yellow solution was freeze-pump-thaw degassed and placed under an atmosphere of carbon monoxide to afford a yellow solution and the structurally dynamic product quantitatively by ${ }^{1} \mathrm{H}$ NMR spectroscopy. Removal of volatiles in vacuo and redissolution in $\mathrm{CD}_{2} \mathrm{Cl}_{2}$ gave the static product by ${ }^{1} \mathrm{H}$ NMR spectroscopy: data are consistent with the published values. ${ }^{6}$

${ }^{1} \mathrm{H}$ NMR (500 MHz, $\mathrm{CD}_{2} \mathrm{Cl}_{2}$, signals for biphenyl omitted): $\delta 7.88$ $\left(\mathrm{t},{ }^{2} J_{\mathrm{HH}}=7.8,1 \mathrm{H}, \mathrm{py}\right), 7.68-7.79\left(\mathrm{~m}, 8 \mathrm{H}, \mathrm{Ar}^{\mathrm{F}}\right), 7.56\left(\mathrm{br}, 4 \mathrm{H}, \mathrm{Ar}^{\mathrm{F}}\right)$, $7.88\left(\mathrm{~d},{ }^{2} J_{\mathrm{HH}}=7.8,2 \mathrm{H}, \mathrm{py}\right), 5.45\left(\mathrm{~d},{ }^{2} J_{\mathrm{HH}}=14.7,2 \mathrm{H}, \mathrm{pyCH}_{2}\right), 5.03$ $\left(\mathrm{d},{ }^{2} J_{\mathrm{HH}}=14.7,2 \mathrm{H}\right.$, pyCH $\left.\mathrm{H}_{2}\right), 4.29\left(\mathrm{br}, 2 \mathrm{H}, \mathrm{NCH}_{2}\right), 3.99($ br, $2 \mathrm{H}$, $\left.\mathrm{NCH}_{2}\right), 1.88$ (br, 4H, CH $), 0.99-1.65\left(\mathrm{~m}, 16 \mathrm{H}, \mathrm{CH}_{2}\right)$. IR $\left(\mathrm{CH}_{2} \mathrm{Cl}_{2}\right): \nu(\mathrm{CO}) 1978 \mathrm{~cm}^{-1}$. LR ESI-MS (positive ion): 536.2 $\left([\mathrm{M}]^{+}\right.$, calcd 536.2) $\mathrm{m} / z$.

$\left[\operatorname{lr}(\mathrm{CNC}-12) \mathrm{H}_{2}\left(\mathrm{H}_{2}\right)\right]\left[\mathrm{BAr}_{4}\right]$ (2b). A solution of $[\operatorname{Ir}(\mathrm{CNC}-12)$ (biph)][BAr $\left.{ }_{4}^{\mathrm{F}}\right]$ (1b;32.3 mg, $\left.20.0 \mu \mathrm{mol}\right)$ in $\mathrm{CD}_{2} \mathrm{Cl}_{2}$ (ca. $0.5 \mathrm{~mL}$ ) inside a J. Young valve NMR tube was freeze-pump-thaw degassed and placed under an atmosphere of dihydrogen. The solution was mixed for $24 \mathrm{~h}$ at ambient temperature to afford the product in ca. $95 \%$ yield, which was characterized in situ using ${ }^{1} \mathrm{H}$ and ${ }^{13} \mathrm{C}$ NMR spectroscopy.

${ }^{1} \mathrm{H}$ NMR (500 MHz, $\mathrm{CD}_{2} \mathrm{Cl}_{2} / \mathrm{H}_{2}$ signals for biphenyl omitted): $\delta$ $7.88\left(\mathrm{t},{ }^{3} \mathrm{~J}_{\mathrm{HH}}=7.7,1 \mathrm{H}, \mathrm{py}\right), 7.71-7.75\left(\mathrm{~m}, 8 \mathrm{H}, \mathrm{Ar}^{\mathrm{F}}\right), 7.56(\mathrm{br}, 4 \mathrm{H}$, $\left.\mathrm{Ar}^{\mathrm{F}}\right), 7.54\left(\mathrm{~d},{ }^{3} \mathrm{~J}_{\mathrm{HH}}=7.3,2 \mathrm{H}, \mathrm{py}\right), 7.13(\mathrm{br}, 2 \mathrm{H}, \mathrm{NCH}), 7.00(\mathrm{br}, 2 \mathrm{H}$, $\mathrm{NCH}), 5.09\left(\mathrm{br}, 4 \mathrm{H}, \mathrm{pyCH}{ }_{2}\right), 4.02\left(\mathrm{br}, 4 \mathrm{H}, \mathrm{NCH}_{2}\right), 1.72-1.86(\mathrm{~m}$, $\left.4 \mathrm{H}, \mathrm{CH}_{2}\right), 1.26-1.54\left(\mathrm{~m}, 16 \mathrm{H}, \mathrm{CH}_{2}\right),-9.46,(\mathrm{vbr}, \mathrm{fwhm}=230 \mathrm{~Hz}$, $\left.T_{1}=94 \pm 5 \mathrm{~ms}, 4 \mathrm{H}, \mathrm{IrH}\right) .{ }^{1} \mathrm{H} \mathrm{NMR}\left(500 \mathrm{MHz}, \mathrm{CD}_{2} \mathrm{Cl}_{2} / \mathrm{H}_{2}, 200 \mathrm{~K}\right.$, selected data): $\delta-9.56$, (br, fwhm $=50 \mathrm{~Hz}, T_{1}=29 \pm 3 \mathrm{~ms}, 4 \mathrm{H}$, IrH). ${ }^{13} \mathrm{C}\left\{{ }^{1} \mathrm{H}\right\}$ NMR (126 MHz, $\mathrm{CD}_{2} \mathrm{Cl}_{2} / \mathrm{H}_{2}$, signals for biphenyl omitted): $\delta 162.3\left(\mathrm{q},{ }^{1} J_{\mathrm{BC}}=50, \mathrm{Ar}^{\mathrm{F}}\right), 156.8(\mathrm{~s}, \mathrm{py}), 140.1(\mathrm{~s}, \mathrm{py})$, $135.3\left(\mathrm{~s}, \mathrm{Ar}^{\mathrm{F}}\right), 129.4\left(\mathrm{qq},{ }^{2} J_{\mathrm{FC}}=32,{ }^{3} J_{\mathrm{BC}}=3, \mathrm{Ar}^{\mathrm{F}}\right), 125.2\left(\mathrm{q},{ }^{1} J_{\mathrm{FC}}=\right.$ 272, $\left.\operatorname{Ar}^{\mathrm{F}}\right), 125.1$ (s, py), $121.6(\mathrm{~s}, \mathrm{NCH}), 120.3(\mathrm{~s}, \mathrm{NCH}), 118.1$ $\left(\right.$ sept, $\left.{ }^{3} J_{\mathrm{FC}=} 4, \mathrm{Ar}^{\mathrm{F}}\right), 59.0\left(\mathrm{br}, \mathrm{fwhm}=90 \mathrm{~Hz}, \mathrm{pyCH}_{2}\right), 52.1\left(\mathrm{~s}, \mathrm{NCH}_{2}\right)$, $30.3\left(\mathrm{~s}, \mathrm{CH}_{2}\right), 27.8\left(\mathrm{~s}, \mathrm{CH}_{2}\right), 27.7\left(\mathrm{~s}, \mathrm{CH}_{2}\right), 27.0\left(\mathrm{~s}, \mathrm{CH}_{2}\right), 25.5(\mathrm{~s}$, $\mathrm{CH}_{2}$ ). The carbenic resonance was not unambiguously located at this temperature.

Subsequent removal of volatiles in vacuo and redissolution in $\mathrm{CD}_{2} \mathrm{Cl}_{2}$ gave a major product that analyzed as $\left[\operatorname{Ir}(\mathrm{CNC}-12) \mathrm{H}_{2}\right]$ $\left[\mathrm{BAr}_{4}{ }_{4}\right]$ (data below). A complex of this formulation was also obtained as the major species when the reaction mixture was layered with excess hexane and stored at $-30{ }^{\circ} \mathrm{C}$ (red gum, Figure S42).

${ }^{1} \mathrm{H}$ NMR (500 MHz, $\mathrm{CD}_{2} \mathrm{Cl}_{2}$, signals for biphenyl omitted): $\delta 7.87$ $\left(\mathrm{t},{ }^{3} J_{\mathrm{HH}}=7.8,1 \mathrm{H}, \mathrm{py}\right), 7.71-7.75\left(\mathrm{~m}, 8 \mathrm{H}, \mathrm{Ar}^{\mathrm{F}}\right), 7.56\left(\mathrm{br}, 4 \mathrm{H}, \mathrm{Ar}^{\mathrm{F}}\right)$, $7.51\left(\mathrm{~d},{ }^{3} J_{\mathrm{HH}}=7.9,2 \mathrm{H}, \mathrm{py}\right), 7.16(\mathrm{br}, 2 \mathrm{H}, \mathrm{NCH}), 7.07(\mathrm{br}, 2 \mathrm{H}$, $\mathrm{NCH}), 5.18\left(\mathrm{~s}, 4 \mathrm{H}, \mathrm{pyCH}_{2}\right), 4.22-4.05\left(\mathrm{~m}, 4 \mathrm{H}, \mathrm{NCH}_{2}\right), 1.94-1.72$ $\left(\mathrm{m}, 4 \mathrm{H}, \mathrm{CH}_{2}\right), 1.66-1.04\left(\mathrm{~m}, 16 \mathrm{H}, \mathrm{CH}_{2}\right),-24.53,\left(\mathrm{br}, T_{1}=727 \pm\right.$ $16 \mathrm{~ms}, 2 \mathrm{H}, \mathrm{IrH})$.

$\left[\operatorname{Ir}(\mathrm{CNC}-12) \mathrm{H}_{2}(\mathrm{CO})\right]\left[\mathrm{BAr}_{4}\right]$ (4). A solution of $[\operatorname{Ir}(\mathrm{CNC}-12)$ (biph)][BAr $\left.{ }_{4}{ }_{4}\right](\mathbf{l b} ; 31.2 \mathrm{mg}, 19.3 \mu \mathrm{mol})$ in $\mathrm{CH}_{2} \mathrm{Cl}_{2}$ (ca. $1 \mathrm{~mL}$ ) was freeze-pump-thaw degassed and placed under an atmosphere of dihydrogen. After mixing for $24 \mathrm{~h}$ at ambient temperature, the resulting pale yellow solution was freeze-pump-thaw degassed and placed under an atmosphere of carbon monoxide. Following stirring for $30 \mathrm{~min}$, the product was precipitated by addition of excess hexane, isolated by filtration, washed with hexane (ca. $3 \times 1 \mathrm{~mL})$, and then dried in vacuo. Yield: $20.0 \mathrm{mg}$ (69\%, colorless foam).

${ }^{1} \mathrm{H}$ NMR (500 MHz, $\left.\mathrm{CD}_{2} \mathrm{Cl}_{2}\right): \delta 7.92\left(\mathrm{t},{ }^{3} J_{\mathrm{HH}}=7.9,1 \mathrm{H}, \mathrm{py}\right)$, 7.70-7.75 (m, 8H, Ar $\left.{ }^{\mathrm{F}}\right), 7.58\left(\mathrm{~d},{ }^{3} J_{\mathrm{HH}}=7.9,2 \mathrm{H}, \mathrm{py}\right), 7.56(\mathrm{br}, 4 \mathrm{H}$, $\left.\mathrm{Ar}^{\mathrm{F}}\right), 7.21\left(\mathrm{~d},{ }^{3} J_{\mathrm{HH}}=2.0,2 \mathrm{H}, \mathrm{NCH}\right), 7.07\left(\mathrm{~d},{ }^{3} J_{\mathrm{HH}}=2.0,2 \mathrm{H}, \mathrm{NCH}\right)$, $5.17\left(\mathrm{~d},{ }^{2} \mathrm{~J}_{\mathrm{HH}}=15.1,2 \mathrm{H}, \mathrm{pyCH}_{2}\right), 5.07\left(\mathrm{br}, 2 \mathrm{H}, \mathrm{pyCH}_{2}\right), 4.07(\mathrm{br}$, $\left.4 \mathrm{H}, \mathrm{NCH}_{2}\right), 1.83\left(\right.$ app. p, $\left.J=7,4 \mathrm{H}, \mathrm{CH}_{2}\right), 1.28-1.56(\mathrm{~m}, 16 \mathrm{H}$, $\left.\mathrm{CH}_{2}\right),-7.33\left(\mathrm{~d},{ }^{2} J_{\mathrm{HH}}=2.9, T_{1}=1120 \pm 18 \mathrm{~ms}, 1 \mathrm{H}, \mathrm{IrH}\right),-17.69(\mathrm{~d}$, $\left.{ }^{2} J_{\mathrm{HH}}=2.9, T_{1}=950 \pm 9 \mathrm{~ms}, 1 \mathrm{H}, \mathrm{IrH}\right) \cdot{ }^{13} \mathrm{C}\left\{{ }^{1} \mathrm{H}\right\} \mathrm{NMR}(126 \mathrm{MHz}$, $\left.\mathrm{CD}_{2} \mathrm{Cl}_{2}\right): \delta 174.0(\mathrm{~s}, \operatorname{IrCO}), 162.3\left(\mathrm{q},{ }^{1} J_{\mathrm{BC}}=50, \mathrm{Ar}^{\mathrm{F}}\right), 158.0(\mathrm{~s}$,
$\mathrm{NCN}$ ), 156.0 (s, py), 140.8 (s, py), $135.4\left(\mathrm{~s}, \mathrm{Ar}^{\mathrm{F}}\right), 129.4\left(\mathrm{qq},{ }^{2} J_{\mathrm{FC}}=\right.$ $\left.32,{ }^{3} J_{\mathrm{BC}}=3, \mathrm{Ar}^{\mathrm{F}}\right), 125.3(\mathrm{~s}, \mathrm{py}), 125.2\left(\mathrm{q},{ }^{1} J_{\mathrm{FC}}=272, \mathrm{Ar}^{\mathrm{F}}\right), 121.9(\mathrm{~s}$, $\mathrm{NCH}), 120.9(\mathrm{~s}, \mathrm{NCH}), 118.1\left(\mathrm{sept},{ }^{3} \mathrm{~J}_{\mathrm{FC}}=4, \mathrm{Ar}^{\mathrm{F}}\right), 59.5\left(\mathrm{~s}, \mathrm{pyCH}_{2}\right)$, $52.3\left(\mathrm{~s}, \mathrm{NCH}_{2}\right), 30.3\left(\mathrm{~s}, \mathrm{CH}_{2}\right), 27.8\left(\mathrm{~s}, \mathrm{CH}_{2}\right), 27.6\left(\mathrm{~s}, \mathrm{CH}_{2}\right), 26.9(\mathrm{~s}$, $\left.\mathrm{CH}_{2}\right), 25.5\left(\mathrm{~s}, \mathrm{CH}_{2}\right)$. IR $\left(\mathrm{CH}_{2} \mathrm{Cl}_{2}\right): \nu(\mathrm{CO}) 2062 \mathrm{~cm}^{-1}$. HR ESI-MS (positive ion, $4 \mathrm{kV}): 628.2622\left([M]^{+}\right.$, calcd 628.2623) $\mathrm{m} / z$.

Satisfactory microanalysis could not be obtained, presumably due to low stability in the solid state (Figure S46).

Crystallographic Details. Full details about the collection, solution, and refinement are documented in the CIF files, which have been deposited with the Cambridge Crystallographic Data Centre under CCDC 1862296-1862299.

Computational Details. Density functional theory calculations were carried out using the ORCA 4.0.1.1 program, ${ }^{29}$ employing Grimme's dispersion corrected $\omega$ B97X-D3 functional, the LANL2DZ basis set and associated effective core potentials for $\mathrm{Rh}$ and Ir, and 6 $31 \mathrm{G}(\mathrm{d}, \mathrm{p})$ basis set for all other atoms. ${ }^{30}$ Minima were verified by analytical vibrational mode analysis. Thermal corrections (298.15 K, 1 $\mathrm{atm})$ were applied to deduce the Gibbs free energies. NBO analyses were carried out using NBO 6.0. ${ }^{17}$ All-electron single-point calculations were carried out on $\mathbf{1}$ employing the same functional and the Sapporo-DKH3-DZP-2012 basis set on $\mathrm{Rh}$ and $\mathrm{Ir}^{28}$ respectively, and the converged wave functions were used to carry out QTAIM analysis with AIMAll. ${ }^{18}$

\section{ASSOCIATED CONTENT}

\section{(S) Supporting Information}

(PDF) The Supporting Information is available free of charge on the ACS Publications website at DOI: 10.1021/ acs.organomet.8b00595.

Additional experimental and computational details, NMR, IR and ESI-MS spectra of new compounds, and selected reactions (PDF)

Undergraduate teaching materials (PDF)

Cartesian coordinates for the calculated structures (XYZ)

\section{Accession Codes}

CCDC 1862296-1862299 contain the supplementary crystallographic data for this paper. These data can be obtained free of charge via www.ccdc.cam.ac.uk/data_request/cif, or by emailing data_request@ccdc.cam.ac.uk, or by contacting The Cambridge Crystallographic Data Centre, 12 Union Road, Cambridge CB2 1EZ, UK; fax: +44 1223336033.

\section{AUTHOR INFORMATION}

\section{Corresponding Author}

*E-mail for A.B.C.: a.b.chaplin@warwick.ac.uk.

\section{ORCID}

Matthew R. Gyton: 0000-0002-7565-5154

Baptiste Leforestier: 0000-0001-8547-6021

Adrian B. Chaplin: 0000-0003-4286-8791

\section{Notes}

The authors declare no competing financial interest.

\section{ACKNOWLEDGMENTS}

We thank the European Research Council (ERC, grant agreement 637313) and Royal Society (UF100592, UF150675, A.B.C.) for financial support. High-resolution mass spectrometry data were collected using instruments purchased through support from Advantage West Midlands and the European Regional Development Fund. Crystallographic data were collected using an instrument that received funding from the ERC under the European Union's Horizon 
2020 research and innovation program (grant agreement No. 637313). We thank Dr. C. André Ohlin for access to specialist computational resources.

\section{REFERENCES}

(1) (a) Pincer Compounds: Chemistry and Applications; MoralesMorales, D., Ed.; Elsevier: 2018; Vol. 1. (b) Kumar, A.; Bhatti, T. M.; Goldman, A. S. Dehydrogenation of Alkanes and Aliphatic Groups by Pincer-Ligated Metal Complexes. Chem. Rev. 2017, 117, 1235712384. (c) Organometallic Pincer Chemistry; van Koten, G., Milstein, D., Eds.; Springer: 2013; Topics in Organometallic Chemistry Vol. 40. (d) van der Boom, M. E.; Milstein, D. Cyclometalated PhosphineBased Pincer Complexes: Mechanistic Insight in Catalysis, Coordination, and Bond Activation. Chem. Rev. 2003, 103, 1759-1792. (e) Albrecht, M.; van Koten, G. Platinum Group Organometallics Based on "Pincer" Complexes: Sensors, Switches, and Catalysts. Angew. Chem., Int. Ed. 2001, 40, 3750-3781.

(2) (a) Storey, C. M.; Cook, H. P.; Chaplin, A. B. Complexes of NHC-Based CEC Pincer Ligands: Structural Diversity and Applications. In Pincer Compounds: Chemistry and Applications; Morales-Morales, D., Ed.; Elsevier: 2018; Vol. 1, pp 173-189. (b) Andrew, R. E.; González-Sebastián, L.; Chaplin, A. B. NHC-Based Pincer Ligands: Carbenes with a Bite. Dalton Trans. 2016, 45, 12991305.

(3) For notable rhodium and iridium examples see: (a) Kleinhans, G.; Guisado-Barrios, G.; Liles, D. C.; Bertrand, G.; Bezuidenhout, D. I. A Rhodium(I)-Oxygen Adduct as a Selective Catalyst for One-Pot Sequential Alkyne Dimerization-Hydrothiolation Tandem Reactions. Chem. Commun. 2016, 52, 3504-3507. (b) Chianese, A. R.; Drance, M. J.; Jensen, K. H.; McCollom, S. P.; Yusufova, N.; Shaner, S. E.; Shopov, D. Y.; Tendler, J. A. Acceptorless Alkane Dehydrogenation Catalyzed by Iridium CCC-Pincer Complexes. Organometallics 2014, 33, 457-464. (c) Knapp, S. M. M.; Shaner, S. E.; Kim, D.; Shopov, D. Y.; Tendler, J. A.; Pudalov, D. M.; Chianese, A. R. Mechanistic Studies of Alkene Isomerization Catalyzed by CCC-Pincer Complexes of Iridium. Organometallics 2014, 33, 473-484. (d) Darmawan, N.; Yang, C.-H.; Mauro, M.; Raynal, M.; Heun, S.; Pan, J.; Buchholz, H.; Braunstein, P.; De Cola, L. Efficient Near-UV Emitters Based on Cationic Bis-Pincer Iridium(III) Carbene Complexes. Inorg. Chem. 2013, 52, 10756-10765. (e) Bauer, E. B.; Andavan, G. T. S.; Hollis, T. K.; Rubio, R. J.; Cho, J.; Kuchenbeiser, G. R.; Helgert, T. R.; Letko, C. S.; Tham, F. S. Air- and Water-Stable Catalysts for Hydroamination/Cyclization. Synthesis and Application of CCC-NHC Pincer Complexes of Rh and Ir. Org. Lett. 2008, 10, 1175-1178.

(4) Hartwig, J. F. Organotransition Metal Chemistry: From Bonding to Catalysis; University Science Books: 2010; Vol. 1.

(5) (a) Seyboldt, A.; Wucher, B.; Alles, M.; Rominger, F.; MaichleMössmer, C.; Kunz, D. Synthesis and Reactivity of an Ir(I) Carbonyl Complex Bearing a Carbazolide-Bis(NHC) Pincer Ligand. J. Organomet. Chem. 2015, 775, 202-208. (b) Wucher, B.; Moser, M.; Schumacher, S. A.; Rominger, F.; Kunz, D. First X-Ray Structure Analyses of Rhodium(III) $\eta^{1}$-Allyl Complexes and a Mechanism for Allylic Isomerization Reactions. Angew. Chem., Int. Ed. 2009, 48, 4417-4421. (c) Moser, M.; Wucher, B.; Kunz, D.; Rominger, F. 1,8Bis(imidazolin-2-yliden-1-yl)carbazolide (bimca): A New CNC Pincer-Type Ligand with Strong Electron-Donating Properties. Facile Oxidative Addition of Methyl Iodide to $\mathrm{Rh}$ (bimca)(CO). Organometallics 2007, 26, 1024-1030. (d) Wright, J. A.; Danopoulos, A. A.; Motherwell, W. B.; Carroll, R. J.; Ellwood, S.; Saßmannshausen, J. Pincer" N-Heterocyclic Carbene Complexes of Rhodium Functionalised with Pyridyl and Bipyridyl Donors. Eur. J. Inorg. Chem. 2006, 2006, 4857-4865. (e) Wilson, J. M.; Sunley, G. J.; Adams, H.; Haynes, A. Oxidative addition of MeI to cationic $\mathrm{Rh}(\mathrm{I})$ carbonyl complexes with pyridyl bis(carbene) ligands. J. Organomet. Chem. 2005, 690, 6089-6095.

(6) Andrew, R. E.; Chaplin, A. B. Synthesis and Reactivity of NHCBased Rhodium Macrocycles. Inorg. Chem. 2015, 54, 312-322.
(7) Andrew, R. E.; Storey, C. M.; Chaplin, A. B. Well-Defined Coinage Metal Transfer Agents for the Synthesis of NHC-Based Nickel, Rhodium and Palladium Macrocycles. Dalton Trans. 2016, 45, 8937-8944.

(8) Storey, C. M.; Gyton, M. R.; Andrew, R. E.; Chaplin, A. B. Terminal Alkyne Coupling Reactions through a Ring: Mechanistic Insights and Regiochemical Switching. Angew. Chem., Int. Ed. 2018, 57, 12003-12006.

(9) Knighton, R. C.; Emerson-King, J.; Rourke, J. P.; Ohlin, C. A.; Chaplin, A. B. Solution, Solid-State, and Computational Analysis of Agostic Interactions in a Coherent Set of Low-Coordinate Rhodium(III) and Iridium(III) Complexes. Chem. - Eur. J. 2018, 24, 49274938.

(10) Andrew, R. E.; Ferdani, D. W.; Ohlin, C. A.; Chaplin, A. B. Coordination Induced Atropisomerism in an NHC-Based Rhodium Macrocycle. Organometallics 2015, 34, 913-917.

(11) Andrew, R. E.; Chaplin, A. B. Synthesis, Structure and Dynamics of NHC-Based Palladium Macrocycles. Dalton Trans. 2014, 43, 1413-1423.

(12) Brookhart, M.; Green, M. L. H.; Parkin, G. Agostic Interactions in Transition Metal Compounds. Proc. Natl. Acad. Sci. U. S. A. 2007, $104,6908-6914$.

(13) Iverson, C. N.; Jones, W. D. Rhodium-Catalyzed Activation and Functionalization of the $\mathrm{C}-\mathrm{C}$ Bond of Biphenylene. Organometallics 2001, 20, 5745-5750.

(14) Lu, Z.; Jun, C.-H.; de Gala, S. R.; Sigalas, M. P.; Eisenstein, O.; Crabtree, R. H. Geometrically Distorted and Redox-Active Organometallic Iridium Complexes Containing Biphenyl-2,2'-Diyl. Organometallics 1995, 14, 1168-1175.

(15) For a representative example of detection of agostic interactions by this method see: Huang, D.; Streib, W. E.; Bollinger, J. C.; Caulton, K. G.; Winter, R. F.; Scheiring, T. 14-Electron Four-Coordinate $\mathrm{Ru}$ (II) Carbyl Complexes and Their Five-Coordinate Precursors: Synthesis, Double Agostic Interactions, and Reactivity. J. Am. Chem. Soc. 1999, 121, 8087-8097.

(16) Alternative $\delta$-agostic isomers $(\boldsymbol{\delta}$-1) are calculated to be $\Delta G=$ 3.7 (1a) and $3.8(\mathbf{1 b}) \mathrm{kcal} \mathrm{mol}^{-1}$ higher in energy. They are also notable for longer $\mathrm{M} \cdots \mathrm{H}-\mathrm{C}$ distances (3.23 and $3.12 \AA$ ) and more linear $\mathrm{M} \cdots \mathrm{H}-\mathrm{C}$ angles $\left(144.7\right.$ and $\left.142.7^{\circ}\right)$.

(17) Glendening, E. D.; Badenhoop, J. K.; Reed, A. E.; Carpenter, J. E.; Bohmann, J. A.; Morales, C. M.; Landis, C. R.; Weinhold, F. NBO v. 6.0; http://nbo6.chem.wisc.edu.

(18) Keith, T. A. AIMAll v 17.11.14; http://aim.tkgrist-mill.com.

(19) (a) Lein, M. Characterization of Agostic Interactions in Theory and Computation. Coord. Chem. Rev. 2009, 253, 625-634. (b) Scherer, W.; McGrady, G. S. Agostic Interactions in $\mathrm{d}^{0}$ Metal Alkyl Complexes. Angew. Chem., Int. Ed. 2004, 43, 1782-1806.

(20) Pregosin, P. S. NMR in Organometallic Chemistry; Wiley-VCH: Weinheim, Germany, 2012.

(21) Thermolysis of $\mathbf{3 a}$ in the absence of $\mathbf{1} \mathbf{b}$ under otherwise equivalent conditions results in the formation of a $1 / 1 / 1$ mixture of 1a, B, and 9-fluorenone $\left(\delta 7.63,7.57,7.51,7.31 ; 1716 \mathrm{~cm}^{-1}\right.$; see the Supporting Information). Similar reactivity has been noted before for rhodium: Perthuisot, C.; Edelbach, B. L.; Zubris, D. L.; Jones, W. D. $\mathrm{C}-\mathrm{C}$ Activation in Biphenylene. Synthesis, Structure, and Reactivity of $\left(\mathrm{C}_{5} \mathrm{Me}_{5}\right)_{2} \mathrm{M}_{2}\left(2,2^{\prime}\right.$-biphenyl $)(\mathrm{M}=\mathrm{Rh}, \mathrm{Co})$. Organometallics 1997, $16,2016-2023$. Under these conditions $3 b$ is thermally stable.

(22) Pike, S. D.; Crimmin, M. R.; Chaplin, A. B. Organometallic Chemistry Using Partially Fluorinated Benzenes. Chem. Commun. 2017, 53, 3615-3633.

(23) (a) Crabtree, R. H. Dihydrogen Complexation. Chem. Rev. 2016, 116, 8750-8769. (b) Heinekey, D. M.; Oldham, W. J. Coordination Chemistry of Dihydrogen. Chem. Rev. 1993, 93, 913926. (c) Desrosiers, P. J.; Cai, L.; Lin, Z.; Richards, R.; Halpern, J. Assessment of the " $T_{1}$ Criterion" for Distinguishing between Classical and Nonclassical Transition-Metal Hydrides: Hydride Relaxation Rates in Tris(triarylphosphine)osmium Tetrahydrides and Related Polyhydrides. J. Am. Chem. Soc. 1991, 113, 4173-4184. (d) Hamilton, D. G.; Crabtree, R. H. An NMR Method for Distinguishing Classical 
from Nonclassical Structures in Transition-Metal Polyhydrides. J. Am. Chem. Soc. 1988, 110, 4126-4133.

(24) Alternative structures featuring $\delta$-agostic $\left(\boldsymbol{\delta}-\mathbf{2}^{\prime \prime}\right)$ and $\kappa^{1} \mathrm{Cl}^{-}$ $\mathrm{CH}_{2} \mathrm{Cl}_{2}$ (DCM-2") were optimized, for both rhodium and iridium but calculated to be higher in energy than $\boldsymbol{\varepsilon}-\mathbf{2}^{\prime \prime}$ (see the Supporting Information).

(25) (a) Esteruelas, M. A.; López, A. M.; Oliván, M. Polyhydrides of Platinum Group Metals: Nonclassical Interactions and $\Sigma$-Bond Activation Reactions. Chem. Rev. 2016, 116, 8770-8847. (b) Adams, G. M.; Chadwick, F. M.; Pike, S. D.; Weller, A. S. A $\mathrm{CH}_{2} \mathrm{Cl}_{2}$ complex of a $[\mathrm{Rh} \text { (pincer) }]^{+}$cation. Dalton Trans. 2015, 44, 6340-6342. (c) Chaplin, A. B.; Weller, A. S. $\left[\mathrm{Rh}\left\{\mathrm{NC}_{5} \mathrm{H}_{3}-2,6-\right.\right.$ $\left.\left.\left(\mathrm{CH}_{2} \mathrm{P}^{\mathrm{t}} \mathrm{Bu}_{2}\right)_{2}\right\}\left(\mathrm{PCy}_{3}\right)\right]\left[\mathrm{BAr}_{4}^{\mathrm{F}}\right]$ : A Latent Low-Coordinate Rhodium(I) PNP Pincer Compound. Organometallics 2011, 30, 4466-4469.

(26) Findlater, M.; Schultz, K. M.; Bernskoetter, W. H.; CartwrightSykes, A.; Heinekey, D. M.; Brookhart, M. Dihydrogen Complexes of Iridium and Rhodium. Inorg. Chem. 2012, 51, 4672-4678.

(27) (a) Holmes, A. J.; Rayner, P. J.; Cowley, M. J.; Green, G. G. R.; Whitwood, A. C.; Duckett, S. B. The reaction of an iridium PNP complex with parahydrogen facilitates polarisation transfer without chemical change. Dalton Trans. 2015, 44, 1077-1083. (b) Hermann, D.; Gandelman, M.; Rozenberg, H.; Shimon, L. J. W.; Milstein, D. Synthesis, Structure, and Reactivity of New Rhodium and Iridium Complexes, Bearing a Highly Electron-Donating PNP System. Iridium-Mediated Vinylic $\mathrm{C}-\mathrm{H}$ Bond Activation. Organometallics 2002, 21, 812-818. (c) Bianchini, C.; Moneti, S.; Peruzzini, M.; Vizza, F. Synthesis and Reactivity of the Labile Dihydrogen Complex $\left[\left\{\mathrm{MeC}\left(\mathrm{CH}_{2} \mathrm{PPh}_{2}\right)_{3}\right\} \operatorname{Ir}\left(\mathrm{H}_{2}\right)(\mathrm{H})_{2}\right] \mathrm{BPh}_{4}$. Inorg. Chem. 1997, 36, 58185825 .

(28) Buschmann, W. E.; Miller, J. S.; Bowman-James, K.; Miller, C. N. Synthesis of $\left[\mathrm{M}^{\mathrm{II}}(\mathrm{NCMe})_{6}\right]^{2+}(\mathrm{M}=\mathrm{V}, \mathrm{Cr}, \mathrm{Mn}, \mathrm{Fe}, \mathrm{Co}, \mathrm{Ni})$ Salts of Tetra[3,5-bis(trifluoromethyl)phenyl]borate. Inorg. Synth. 2002, 33, $83-91$.

(29) (a) Neese, F. Software update: the ORCA program system, version 4.0. Wiley Interdiscip. Rev. Comput. Mol. Sci. 2018, 8, e13271333. (b) Neese, F. The ORCA program system. Wiley Interdiscip. Rev. Comput. Mol. Sci. 2012, 2, 73-78.

(30) (a) Noro, T.; Sekiya, M.; Koga, T. Sapporo-(DKH3)-nZP ( $n=$ $D, T, Q)$ sets for the sixth period s-, d-, and p-block atoms. Theor. Chem. Acc. 2013, 132, 1363-1368. (b) Lin, Y.-S.; Li, G.-D.; Mao, S.P.; Chai, J.-D. Long-Range Corrected Hybrid Density Functionals with Improved Dispersion Corrections. J. Chem. Theory Comput. 2013, 9, 263-272. (c) Sekiya, M.; Noro, T.; Koga, T.; Shimazaki, T. Relativistic segmented contraction basis sets with core-valence correlation effects for atoms ${ }_{57} \mathrm{La}$ through ${ }_{71} \mathrm{Lu}$ : Sapporo-DK- $n \mathrm{ZP}$ sets $(n=\mathrm{D}, \mathrm{T}, \mathrm{Q})$. Theor. Chem. Acc. 2012, 131, 1247-1255. (d) Grimme, S.; Antony, J.; Ehrlich, S.; Krieg, H. A consistent and accurate $a b$ initio parametrization of density functional dispersion correction (DFT-D) for the 94 elements H-Pu. J. Chem. Phys. 2010, 132, 154104-154122. (e) Hay, P. J.; Wadt, W. R. Ab initio effective core potentials for molecular calculations. Potentials for $\mathrm{K}$ to $\mathrm{Au}$ including the outermost core orbitals. J. Chem. Phys. 1985, 82, 299310. (f) Wadt, W. R.; Hay, P. J. Ab initio effective core potentials for molecular calculations. Potentials for main group elements $\mathrm{Na}$ to $\mathrm{Bi}$. J. Chem. Phys. 1985, 82, 284-298. (g) Hariharan, P. C.; Pople, J. A. The influence of polarization functions on molecular orbital hydrogenation energies. Theor. Chim. Acta 1973, 28, 213-222. (h) Hehre, W. J.; Ditchfield, R.; Pople, J. A. Self-Consistent Molecular Orbital Methods. XII. Further Extensions of Gaussian-Type Basis Sets for Use in Molecular Orbital Studies of Organic Molecules. J. Chem. Phys. 1972, $56,2257-2261$. 